\title{
Entrepreneurship policy and the financing of young innovative companies: evidence from the Italian Startup Act
}

\author{
Emanuele Giraudo ${ }^{\mathrm{a}}$, Giancarlo Giudici ${ }^{\mathrm{a}}$, Luca Grilli ${ }^{\mathrm{a} *}$ \\ ${ }^{a}$ Politecnico di Milano, Department of Management, Economics and Industrial Engineering, \\ Via R. Lambruschini 4/b, 20156, Milan, Italy \\ E.mails: emanuele.giraudo@polimi.it giancarlo.giudici@polimi.it luca.grilli@polimi.it \\ * Corresponding author. Phone: +39 022399 3955; fax: +39 0223992710.
}

\begin{abstract}
While there is a general consensus that young innovative companies (YICs) need special attention by public policy which should aim at alleviating the financial constraints these firms commonly suffer, much less agreement has been reached on the most effective policy instruments reputed to accomplish the task. In this respect, if the scientific debate has very much revolved around the dilemma about the crowding-in or crowding-out effect of public R\&D subsidies to firms, there is a dearth of scientific studies which analyse the effectiveness and potential interrelations of different policy instruments which at the same time and in the same institutional context are offered to YICs. By taking advantage of the Italian Startup Act issued in 2012, we analyse, for the first time, the possible existence of interrelationships between firm access to a Government-guaranteed (GG) bank loan program and fiscal incentives for venture capital (VC) equity investments. Results suggest two important facts. First, the two mechanisms appear to be functional to different typologies of YICs. Second, VC investments significantly reduce the probability to access GG bank loans. Overall, our analysis highlights a sort of "institutional division of labour" between the two measures and depicts what we label as a Task segmentation effect.
\end{abstract}

Keywords: Young Innovative Companies; Venture Capital; Government-guaranteed bank loan; Entrepreneurship Policy; Policy Measures Coordination

JEL Codes: 038; G24

Acknowledgements. Authors are indebted to the Editor and two anonymous referees for helpful comments and suggestions. We are also thankful to participants to the ENTFIN Conference 2016 held in Lyon, the AiIG Conference 2016 held in Bergamo, the 2018 R\&D Management Conference held in Milan, the Herrenhausen Conference 2019 held in Hanover. We are grateful to Edoardo Girelli, Simone Melchionda, Edoardo Pantanella and Danilo Sesana for valuable research assistance. We also wish to thank Hans Christian Kongsted, Rocco Mosconi and Vera Rocha for their advice in the econometric analysis. Responsibility for any errors lies solely with the authors. 


\title{
Entrepreneurship policy and the financing of young innovative companies: evidence from the Italian Startup Act
}

\begin{abstract}
While there is a general consensus that young innovative companies (YICs) need special attention by public policy which should aim at alleviating the financial constraints these firms commonly suffer, much less agreement has been reached on the most effective policy instruments reputed to accomplish the task. In this respect, if the scientific debate has very much revolved around the dilemma about the crowding-in or crowding-out effect of public $\mathrm{R} \& \mathrm{D}$ subsidies to firms, there is a dearth of scientific studies which analyse the effectiveness and potential interrelations of different policy instruments which at the same time and in the same institutional context are offered to YICs. By taking advantage of the Italian Startup Act issued in 2012, we analyse, for the first time, the possible existence of interrelationships between firm access to a Government-guaranteed (GG) bank loan program and fiscal incentives for venture capital (VC) equity investments. Results suggest two important facts. First, the two mechanisms appear to be functional to different typologies of YICs. Second, VC investments significantly reduce the probability to access GG bank loans. Overall, our analysis highlights a sort of "institutional division of labour" between the two measures and depicts what we label as a Task segmentation effect.
\end{abstract}

Keywords: Young Innovative Companies; Venture Capital; Government-guaranteed bank loan; Entrepreneurship Policy; Policy Measures Coordination

JEL Codes: 038; G24 


\section{Introduction}

Entrepreneurial activity in technological advanced sectors is deemed to be a major source of innovation, qualified employment and economic growth (Schumpeter, 1911). Recently, the scientific literature has increasingly focused its attention on the so-called young innovative companies (YICs). Mas-Tur and Moya (2015, p. 1432) identify YICs as small and young firms “with great potential to develop innovations for commercial applications and create value for society” (see also Schneider and Veugelers, 2010; Czarnitzki and Delanote, 2013). These firms are characterized by a specific attitude to grasp technical innovation and they often stimulate the development of new technological paradigms, play a disciplining role towards established leading incumbents, open up new market segments and favour the flow of knowledge and competencies inter- and intra- several industries (Timmons and Spinelli, 2003; Aghion and Howitt, 2005). Accordingly, this typology of companies has attracted the interest not only of academics but also of many other actors in modern economies, first among everyone, policy makers.

For a long time, governments have designed and implemented several types of interventions in order to alleviate those financing constraints that may hamper the birth and the growth of high-potential YICs and related typology of firms. Policy makers need to step in, as long as these firms are likely to invest less than social optimum. Two main reasons are universally acknowledged to explain the gap between private firms’ investment and its social optimum level. First, the presence of important knowledge spillovers in innovative activities (Nelson, 1959; Arrow, 1962; Teece, 1986; Hall and Lerner, 2010), which may hamper YICs that suffer from inefficient mechanisms of protection of their R\&D investments. Secondly, the existence of relevant capital market imperfections which are specifically severe for young and risky startups (Hall, 2002; Revest and Sapio, 2012). Hall and Lerner (2010) provide a list of the reasons which can create a gap between external and internal sources of financing for an 
innovative company: (i) asymmetric information between entrepreneurs and investors causing an adverse selection problem, (ii) agency costs induced by moral hazard, (iii) taxation favouring the financing of innovation through retained earnings instead of raising new capital. Therefore, YICs' chances of obtaining external financing would be made impervious and, as a matter of fact, restricted by the presence of information asymmetries between the company and potential financiers (Peneder, 2008), which give often rise to adverse selection and moral hazard problems among the two parties (Leland and Pyle, 1977; Carpenter and Petersen, 2002). Things get also worse, making more stringent the financial constraints suffered from YICs, because this typology of firms usually lacks stable cash flows, a solid track record and, most importantly, collaterals since YICs usually rely to a great extent on intangible resources (Hall, 2002). ${ }^{1}$

Therefore, if there is a general consensus among both academics and policy makers on the need of direct policies capable to effectively address the financing needs of YICs, much less agreement is discernible on the subsequent question of which policy should be put in place (e.g. see Schneider and Veugelers, 2010). In other words, the fundamental question of how, and if, governments are really able to sustain innovative entrepreneurial activity is far from being resolved.

In particular, several attempts have been implemented by different public institutions in order to ease firms’ access to financial resources. Specifically, government interventions have tried to reduce YICs' financial constraints through instruments like direct subsidies for R\&D and internationalization activities, intellectual property rights protection, taxation and fiscal

\footnotetext{
${ }^{1}$ Interestingly, Mann (2018) shows that some innovative companies may to some extent also rely on patents, which can be pledged as collateral to borrow financial resources. Patents can also be used by startups as signalling devices towards external parties (including financiers and investors, see e.g. Hsu and Ziedonis, 2013). Plumlee et al. (2015) show that banks evaluate firms' patent portfolios when pricing their loans. Hsu et al. (2015) highlight that also bond investors examine patent portfolios to price debt securities. However, patents could often be outof-reach for many YICs, for several reasons, including their non-negligible costs, the low appropriability of innovation in specific industries and the difficulty in evaluating intellectual property rights (Hochberg et al., 2018).
} 
incentives for investors, stimulation of capital markets through equity and venture capital (VC) programs, microfinance and loan guarantee schemes (Minniti, 2008). Admittedly, different governments, at different latitudes, have often opted for different instruments on the basis that policy strategies should be tailored to specific institutional and regional contexts to be truly effective (Wagner and Sternberg, 2004). But, despite a broad literature investigating the role of entrepreneurship policy (Storey, 2003), several issues about the validity and efficacy of these specific interventions are yet to be fully explored (Minniti, 2008). One of the main problems of this stream of literature on entrepreneurship policy evaluation (see for example the case of public R\&D subsidies documented by the scientific review of Zúñiga-Vicente et al., 2014) is that the effectiveness of policy instruments is often analysed in 'isolation'. In other terms, the circumstance that firms are embedded in diverse institutional contexts and are potentially the target of different policy-driven schemes has been largely overlooked in the empirical analyses on the efficacy of policy measures (Grilli et al., 2018a).

In this regard, we argue about the necessity to better understand which typology of firms get access to which type of measures, for then gauging the eventual synergistic effects potentially stemming from the co-existence of different public policy measures available to YICs. Equally important, there is the need to perform this analysis in a controlled institutional setting.

In this respect, the recent Law no. 221 introduced in Italy in 2012 (the "Italian Startup Act”, i.e. also known in Italy as "Decreto Crescita 2.0") and specifically devoted to the support of YICs, offers a valuable opportunity. In fact, we can observe the (eventual) matching between funding suppliers and startups in the presence of an exogenous policy shock which enhanced the available external financing opportunities for a category of firms, i.e. YICs, which has been defined by the policy and that we observe from the beginning of the policy change. This setting should rule out the possibility that the investment dynamics we observe might (at least to some extent) be driven by endogenous self-reinforcing mechanisms arising throughout time in the 
industry. ${ }^{2}$ Secondly, the policy scheme includes at the same time two of the most important and widely adopted measures for the support of the YICs' demand for capital: (i) a program that envisages fiscal incentives for venture capitalists and outside investors who invest in equity capital and (ii) privileged access for YICs to a Government-guaranteed (GG) bank loan program. Venture capital (VC) is often considered for its inherent characteristics as the preferred financing source for YICs (Gompers and Lerner, 2001). VC investors are deemed to better overcoming information asymmetries than other capital market operators (Sahlman, 1990); they provide financial resources but also 'add value' to YICs along a series of important dimensions on which YICs often lack managerial skills and competencies (Hellmann and Puri, 2002). But, even when considering the most developed equity-based financial system like the United States (US), the VC industry ends up financing only a very small fraction of startups (Mulcahy, 2013). As a matter of fact, particularly in bank-based systems like Italy or continental Europe, YICs have to rely on bank debt as the primary source of external financing (Colombo and Grilli, 2007). ${ }^{3}$

Thanks to the Startup Act here considered, all Italian YICs were potentially subject with the same degree of exposure towards the two potential treatments (i) and (ii) above mentioned. We are therefore in the condition to properly investigate the mutual interdependencies arising between the two different sources of financing (and the underlying policy mechanisms). Specifically, we aim at addressing the following questions: do these measures target YICs with similar characteristics or, conversely, do they serve different typologies of YICs? Can these measures be considered complementary, i.e. access to one type of measure eases access to the

\footnotetext{
${ }^{2}$ For example, imitation and isomorphic attitudes (DiMaggio and Powell, 1983) towards successful role models emerging in specific geographical areas have been found to largely and permanently affect the differences in the characteristics of startups operating in the biotechnology industry in the US across different regions (Packalen, 2015). While, in our case, observing YICs from their inception and at the beginning of the institutional change brought in by the policy law, should enable us to analyse the matching between fund providers and YICs in a pure and 'untainted' environment.

${ }^{3}$ Benfratello et al. (2008), among others, underline the importance of bank support to Italian YICs and show a positive effect of local banking development on firms' innovative activities.
} 
other type of measure; or conversely substitute, i.e. access to one type of measure depresses access to the other type? Is there any signalling effect (i.e., 'certification effect', see Lerner, 2002) exerted by the GG bank loans program towards VC investors? Do VC investments have an impact on the likelihood to obtain guaranteed bank loans by YICs?

In order to investigate these issues, we consider a sample of 2,526 Italian YICs and resort to the estimation of a dynamic bivariate survival model (Mosconi and Seri, 2006; Colombo et al., 2007) to highlight simultaneously the determinants of YICs' access to both these modes of financing and the possible existence of substitutability and/or complementarity effects between Government-guaranteed bank loans and VC investments (i.e. whether access to one financing mode decreases or increases the probability for a YIC to access the other mechanism).

The results of our analysis offer unprecedented insights on the financial needs of YICs and deliver important implications in this respect for entrepreneurs, investors and policy makers. In a nutshell, our findings highlight that the two measures serve different types of YICs. In addition, we highlight that YICs obtaining VC funds are less likely to access GG bank debt thereafter.

The remaining of the paper is organized as follows. Section 2 highlights the background literature. Section 3 describes the Italian Startup Act. Section 4 illustrates the methodology and describes the data. Section 5 reports on the empirical analysis, including details on additional evidence and robustness tests produced. Section 6 concludes with final remarks.

\section{Literature review and research hypotheses}

\subsection{Young innovative companies, financial constraints and investors}

YICs are reputed to experience troubles in accessing financial resources, compared to established companies and other young ventures characterized by lower innovativeness: this 
particularly applies to (European) bank-based economies and it is clearly shown by crossnational surveys (see the European Investment Fund report by Kraemer-Eis et al., 2014) and by the academic literature (see the survey of the literature by Revest and Sapio, 2012). The success of innovative ventures heavily relies on investments in R\&D activity, marketing expenses to promote new products and commercialise innovation, resources to hire qualified personnel (Beck and Demirguc-Kunt, 2006). Yet, YICs are generally riskier and failure rates are high (Coad and Rao, 2008); they hardly receive loans from commercial banks because the latter receive pre-determined interest payments but share the losses with shareholders (Hsu et al., 2014). YICs rely on intangible assets, that can be hardly used as collateral for lending (O’Sullivan, 2005). Moreover, they need money for the long run: any interest payment in the startup phase diverts resources from value creation and increases the cash burn rate (Giudici and Paleari, 2000; Mazzucato, 2013). Therefore the access to debt financing through bank loans, which is one of the most common sources of finance for established companies, is a challenge for YICs (Freel, 2007), unless relevant guarantees are provided by the founders, this harming their entrepreneurial boost. The advent of the global financial crisis contributed to further reduce the supply of capital for YICs (North et al., 2013; Lee et al., 2015) especially from banks, and to increase the cost of outside capital.

Equity capital provided by outside professional investors like venture capitalists (VCs) is typically pointed out as the solution to the credit rationing problem (Mina et al., 2013) and to adverse selection and moral hazard problems (Carpenter and Petersen, 2002). VC investors have superior screening capabilities and are typically selective (Sahlman, 1990), require a number of contractual clauses in order to protect their investment (e.g. veto power, supermajority voting, drag-along and tag-along clauses, governance agreements, board representation) and work alongside the founders to increase the value of the venture, by providing managerial competencies, networking and marketing advice (Hellmann and Puri, 
2002; Gompers and Lerner, 2004; Ueda, 2004). Bertoni et al. (2011) show that VC investments positively influence firm growth: the treatment effect of VC investments is of large economic magnitude, especially on the growth of employment. More generally, most of the available empirical evidence largely supports the claim of a positive impact of VC on firm performance, basically irrespective of the latitude and the timing on which analyses are carried on (e.g. Manigart and Van Hyfte, 1999; Kortum and Lerner, 2000; Engel and Keilbach, 2007; Puri and Zarutskie, 2012; Cumming et al., 2017).

\subsection{Bank’s lending and venture capital financing}

Bankers and venture capitalists face the problems of information asymmetry when assessing lending applications and in the evaluation of investment opportunities. These problems are particularly severe when the request comes from new businesses (Binks and Ennew, 1997; Storey, 1994) but, due to the different type of investments, the risks for a commercial bank and a VC are not the same. Banks receive contractually-determined interests and the paid-back principal: they can suffer relevant losses if the YIC fails, but they have no opportunity to gain an upside. Therefore, banks suffer from two types of risks (Parker, 2002): adverse selection lending a failure business (type 1 error), or not lending a successful business (type 2 error) and moral hazard risk, given that the bank is unable to monitor entrepreneurs activity after the loan concession (Binks and Ennew, 1997). In this perspective, banks consider two important issues before lending: the presence of a collateral and the ability for the company to generate cash flows to pay back the principal and the interests (Wynant et al., 1991). Unlike banks, VCs subscribe equity capital and have a residual claim compared to debt holders. On one hand, they are fully exposed in the business failure and they face the possibility that their investment will be illiquid if the new venture does not grow significantly, but on the other hand they enjoy all the upside benefits of success, so they would appreciate high-risk high-return projects while lenders could be more prone to finance startups with a steady and foreseeable growth path. 
This raises the question if banks and venture capitalists target the same types of YICs or not. Even if the financial issues are an important driver, VCs in their investment criteria put great emphasis on the capability of the management team (Muzyka et al., 1996), product characteristics, market characteristics and potential returns (Manigart et al., 1997).

\subsection{Policies for the financial needs of young innovative companies}

Despite the "near universal recognition of the presence of market failures in the provision of finance” for YICs and high-tech startups (Storey and Tether, 1998, p. 1049; see also Hall, 2005), and the alleged consensus on the need for a policy intervention in the field (Schneider and Veugelers, 2010), the debate on the most effective measures to reduce the finance gap for YICs is still quite lively (Colombo et al., 2012).

Policy measures generally vary along several dimensions, but they can be grouped according to the following main aspects: (i) the type of support to be provided to companies (e.g., tax credits, grants, or low interest loans), (ii) whether subsidies are erga-omnes for YICs or rather selective, (iii) the focus of expenditure admissible for public financing, where $R \& D$ usually figures prominently.

Admittedly, the scientific literature has been of little help in imparting to policy makers clear guidelines on identifying the best mechanisms tailored to each specific institutional context (Wagner and Sternberg, 2004). Indeed, much of the scientific debate has revolved around very specific issues. For example, the question of whether public subsidies (especially R\&D grants) crowd-out or crowd-in private monies (Czarnitzki and Fier, 2002; Zúñiga-Vicente et al., 2014). Another more recent lively area of debate is whether the public actor should adopt a 'handson’ approach and establish large governmental venture capital funds and, more generally, whether public (direct or indirect) intervention can trigger the development of a florid venture capital industry (Manigart and Beuselinck, 2001; Leleux and Surlemont, 2003; Cumming and 
MacIntosh, 2006; Da Rin et al., 2006; Cumming, 2007; Brander et al., 2012; Grilli and Murtinu, 2014; Cumming et al., 2017).

While the political discussion is very much open about these issues, from a scientific point of view, it is often argued that one of the major deficiencies in the literature is traceable in the rather Manichean perspective adopted by most studies (see Colombo et al. 2011; Grilli et al., 2018a). In fact, the typical study in the field analyses the effects of a specific policy measure in isolation with respect to (i.e. without taking into account) other possible alternative policy

measures firms may have access to. Secondly, eventual mutual interrelationships arising between different policy measures targeted to YICs have largely remained unexplored. Specifically, although the theme of industrial policy coordination has been investigated from both a theoretical (Cooper and John, 1988; Durlauf, 1993) and an empirical point of view (Rodrik, 1996), the possible rise of policy coordination failures and/or synergies in the specific domain here considered has never been investigated before. This raises our second question: does incentivized access to either VC equity capital or bank debt impact on the probability to access the other alternative source of capital, in a follow-up round?

\subsection{Research hypotheses}

Grounding on the research gap, the specific policy reform here considered enables us to explore, within the same institutional reform, two important research questions:

R1. Do Government-guaranteed bank loans and fiscal incentives for VC equity investments flow towards YICs with the same characteristics or, conversely, the two typologies of subsidized investors target rather different YICs?

$R 2$. Does access to one type of subsidized financing measure facilitate or, conversely, depress access to the other source? 
By combining the answers to these two research questions, it is possible to ascertain four different scenarios as to the effect of the entrepreneurship policy on the financing of YICs. These scenarios are synthesized in Figure 1. A first scenario is labeled Shadow effect. In this case, GG bank loans and subsidized VC investments target very similar YICs, and once accessed one type of financing, the probability for a YIC to access the other is significantly reduced. A second scenario is represented by the Task segmentation effect. The two policy measures help different types of YICs, but again access to one type of measure decreases the probability for a YIC to access the other one. Then, the scenario where GG bank loans and subsidized VC investments flow towards the same type of YICs, and then, once accessed one type of measure, a YIC shows greater probability to access the other financing source, is a typical Matthew effect (Merton, 1968; 1988). Finally, we define a Halo effect (Dollinger et al., 1997; Lerner, 2002; Rosenzweig, 2014) a situation where banks or venture capitalists target different typologies of YICs, and then, access to one type of external funds enhances possibilities for a YIC to get the other source.

\section{[Insert Figure 1]}

Our empirical analysis will enable us to ascertain which of these four different policy scenarios is more likely to refer to YICs, in a specific context where all the companies are subjected to the same measures at the same time.

\section{The Italian Startup Act}

In order to boost the birth of new innovative ventures, in 2012 the Italian Government issued a law (Law no. 221/2012, modified by further amendments, the so-called “Italian Startup Act”) introducing the possibility for young companies to qualify as a YIC (namely "innovative startup”). This status is reserved to limited companies (either Italian companies or branches of 
EU companies registered in Italy), aged less than 5 years, operating in technology-related businesses. YICs have also to comply with one of the following three requirements: (i) be holder, depositary or licensee of a patent or the owner and author of a registered software, (ii) at least one third of employees must hold a Ph.D. or a research tenure (or at least two third must hold a M.Sc. degree), (iii) investments in R\&D should account for at least $15 \%$ of the revenues (or operating costs if they exceed the revenues). Until a company qualifies as a YIC, it cannot distribute dividends and cannot be listed on a stock exchange. The annual revenues must be lower than $€ 5$ million and the company must not be originated from a spin-off or a merger of pre-existing operations.

To YICs (as identified by the law) are granted specific incentives, exemptions and access to privileged (and discounted) services. The retroactive nature of the policy allows access to these support measures not only to new ventures but also to already existing YICs that fulfilled the legal requirements. Measures span over different areas, including the access to equity crowdfunding (Giudici et al., 2013). ${ }^{4}$ For example, Italian YICs can be incorporated on the Internet through digital identification almost for free and they are exempted from any relevant entry fee otherwise due to the Chambers of Commerce. Or again, employees and consultants can be remunerated with stock options and “work for equity” tools enjoying particular reliefs. Moreover, Italian YICs may benefit from fail-fast mechanisms in case of liquidation, so to allow fresh new starts to entrepreneurs. A brief synopsis of the law (and a comparison with legislation in the other EU Member States) is provided by the European Digital Forum (2016). A complete description of the eligibility criteria and of the support measures are available on the governmental website of the Italian Ministry of Economic Development (http://www.mise.gov.it).

\footnotetext{
${ }^{4}$ Before the Startup Act, equity crowdfunding was not allowed in Italy, and it has been reserved to innovative startups only, up to 2015 .
} 
As far as the financing side is concerned, which is the focus of our analysis, two are the policy initiatives of interest. The first initiative is a tax incentive scheme to encourage equity investors for YICs' investments. On the basis of the law, YICs may benefit from robust tax relief on equity investments made by legal entities: a minimum $20 \%$ fiscal deduction up to a maximum investment of $€ 1.8$ million. This provision aims at supporting venture capital investors and benefit those YICs which receive equity financing. The second intervention is a loan Government-guaranteed scheme, designed with the aim to overcome market imperfections in the provision of bank loans to YICs. Italian YICs have priority and simplified access to a Government-guaranteed (GG) bank loan fund (“Fondo di Garanzia”), which offers a partial public guarantee on bank loans. Specifically, the guarantee covers up to $80 \%$ of the credit issued by a commercial bank to the YIC, with an upper limit of $€ 2.5$ million. A YIC must submit its investment plan to the bank, which conducts internally a proper creditworthiness assessment. After that, the bank takes the decision whether to approve the loan request and eventually the guaranteed amount, while "Mediocredito Centrale", the entity that manages the GG fund, makes a further simple formal check, without any additional due diligence.

\section{Data and Methodology}

\subsection{Data}

The sample analysed in this paper is composed of 2,526 Italian YICs. Sample firms were collected starting from the whole population of Italian YICs at December $8^{\text {th }} 2014$, amounting to 3,006 firms. Based on this, we built a new hand-collected longitudinal database gathering complete company information available at November 2016. The observation period starts from 2009 although the year of foundation for (very few) YICs could be antecedent (for the 
age requirement in the law, the foundation year for an Italian YIC cannot be antecedent to 2007). The sources through which data have been collected were mainly three. First, comprehensive accounting and demographics firm information were collected through AIDA, i.e. the Italian fine-grained version of the Amadeus-Bureau Van Dijk database. Second, we used the commercial database provided by the Union of Italian Chambers of Commerce, i.e. Telemaco, which registers all business activities started in Italy and provides (upon payment request) information about shareholders composition and firm financial structure and their evolution over time. The one-by-one visual inspection of each firm's official documentation on capital and debt structure throughout its life was instrumental in discerning the subsidized VC-backed YICs from the non-VC-backed ones, and to record the eventual year of the first professional VC investment. Further confirmatory analysis through secondary sources (e.g. specialized press, corporate websites) was applied in order to reliably identify the VC-backed YICs. Third, data on access by firms to the GG bank loans program with the indication of the year of loan disbursement was provided by the Italian Ministry of Economic Development. ${ }^{5}$ Firm fiscal codes were used in order to anchor all these data across the three different sources.

Then, other information sources were used to complete the set of covariates. We added information on the geographical location of YICs. Specifically, we used several other secondary sources (e.g. Istituto G. Tagliacarne, InfoCamere, Istat) in order to create socioeconomic indicators of the regions (at NUTS 2 level) where YICs are located. Finally, we also included in our analysis variables capturing the contingent phase of the macroeconomic business cycle over years (source: Eurostat).

\subsection{Descriptive statistics}

\footnotetext{
${ }^{5}$ Data in this respect were made available to one of the author for scientific purposes and only thanks to his/her participation to a Ministerial technical committee constituted for the monitoring and evaluation of national policies for the eco-system of Italian innovative startups and SMEs.
} 
As far as the main interest of this study is concerned, the two policy measures seem not to impact equally on the YICs' external financing likelihood (see Table 1). The number of YICs assisted by at least one GG bank loan is relatively small (418 companies representing 16.6\% of the sample), even so, it is much bigger than the number of YICs backed by subsidized VC investments (276 companies, equal to almost 11\%). These data confirm the difficulties to access external financial resources for YICs and the limited size of the VC industry in Continental Europe (Giudici and Roosenboom, 2004). Note also that the number of the firms that accessed both types of financing forms is fairly low, i.e. 48 (1.9\%). This is a first and partial indication that accessing both forms of financing is rather unusual for YICs, suggesting a conceivable substitution effect between the two policy measures.

\section{[Insert Table 1]}

The last part of Table 1 reports statistics about "second transitions": the number of firms that, being backed by one type of financier, have gained access to the other type and the number of firms that in the same year got access to both VC and GG bank loans. Out of the 48 YICs that received funding from both sources, three-fifths (29 firms) obtained the GG bank loan some years after they were invested by a VC, while seven firms obtained a GG bank loan and afterwards they were backed by a VC. Only 12 firms obtained equity capital and guaranteed debt in the same year.

As for other descriptive statistics not reported in the tables, the total accounting value of the company assets at the end of 2015 was lower than $€ 100,000$ in $37 \%$ of the YICs. By the same period, $14 \%$ of the firms had not obtained any revenue yet; while only $29 \%$ (741 companies) had overcome the threshold of $€ 100,000$ in terms of total revenues, with several YICs still in the early stages of their life (sampled YICs are 3.5 years old on average). Even though the Law no. 221/2012 included specific measures aimed at easing the hiring of the workforce, at the end of 2015, 55\% of the YICs still relied entirely on the self-employment of entrepreneurs, and 
$45 \%$ declared salaried employees. As a matter of fact, only $18 \%$ of the startups employed more than three individuals.

\subsection{The econometric model}

We model a YIC’s likelihood to access VC and/or GG bank loans using a dynamic bivariate discrete-time stochastic process. The description of the method is based on Mosconi and Seri (2006) and Colombo et al. (2007). This statistical approach is specifically designed for noncausality analysis in a dynamic process in which the conditions for Granger non-causality can be tested and represented through a Wald test (Mosconi and Seri, 2006). Based on the structure of our dataset, the dynamic process is assimilated to a bivariate discrete-time survival process, where a transition occurs each time a YIC get access to one of the two different types of external funds in a specific year.

We define a binary variable $y_{i t}^{j}(j \in\{A, B\}) ; y_{i t}^{A}=1$ if firm $i$ accesses VC (state A) by the year $t$ and $y_{i t}^{A}=0$ otherwise; and $y_{i t}^{B}=1$ if firm $i$ accesses GG bank loans (state B) by the year $t$ and $y_{i t}^{B}=0$ otherwise, with $t \in\left\{t_{i}^{E}, \ldots, T\right\}$. $t_{i}^{E}$ is the foundation year of the firm $i, T$ is the last year of the observation period, i.e. 2016. For all YICs, at year $t$, only four different states of nature are observable: $0=[0,0] ; 1=[1,0] ; 2=[0,1] ; 3=[1,1]$. The state 0 is relative to YICs that obtained neither VC funds nor GG bank loans. State 1 identifies VC-backed firms that did not access GG bank loans, state 2 captures YICs that obtained a GG bank loan but which are not VC-backed, while state 3 indicates access to both VC and GG bank loans.

A peculiar case of the Mosconi and Seri (2006) model can be obtained when some of the transition probabilities are set to zero. The discrete-time binary model used in this study contemplates five different possible transition probabilities (as Figure 2 illustrates). From state 0 to state 1 or to state 2 the transitions are defined as first transitions, instead transitions from states 1 or 2 to state 3 and from 0 to 3 are defined as second transitions. The model is defined as an absorbing states model (Mosconi and Seri, 2006) and it assumes that transitions between 
states are irreversible. Formally, this means that a firm which has reached the states $y_{i t-1}^{j}=1$ at year $t-1$ will not go back to $y_{i t}^{j}=0$ at year $t$. It means that the transitions from state 1 to state 1 (an additional VC investment), state 2 to 2 (the access to a new GG bank loan) and from state 3 to state 3 are defined as 'no transition' and the status remained the same as the one in year $t$ 1. Accordingly, this also means that the probability of a YIC of being VC-backed (GG bankbacked) at year $t$ if it was already VC-backed (GG bank-backed) at year $t-1$ is equal to 1 .

The model adopts a latent regression approach and poses the assumptions that all firms $i$ access GG bank loan or VC (variable $j$ ), if a latent continuous random variable $y_{i t}^{* j}$ exceeds a threshold level, that without loss of generality is set equal to zero. Given that the variable $y_{i t}^{* j}$ depends on the firm $i$ 's states of nature at year $t-1$, the dynamics are modelled as a typical firstorder Markov chain process. The stationary assumption of transition probabilities implied by a strict first-order Markov process is then relaxed by modelling YIC's access to the two different forms of financing, as a function not only of past realizations of the endogenous variables, i.e. state of nature at year $t-1$, but also as a function of a set of time-varying and unvarying covariates. Following recommendations by Mosconi and Seri (2006), in our analysis all timedependent YIC-specific explanatory variables which may be correlated to firm access to VC or GG bank loan at year $t$, have been lagged at $t-1$, in order to alleviate possible reverse causality problems. Finally, in order to exploit all the available relevant information concerning first transition probabilities in the event that YICs obtain VC and/or GG bank loan during their foundation year, we construct a variable indicating whether a firm is less than one year old. In other words, the variable Dseed $_{i t}$ is defined as follows:

$$
\text { Dseed }_{i t}=\left\{\begin{array}{cc}
1 & t=t_{i}^{E} \\
0 & t>t_{i}^{E}
\end{array}\right.
$$

Lagged time-varying firm-specific explanatory variables (e.g. firm size in terms of employees or firm leverage) are by construction not defined before firm's foundation. The 
same applies to the lagged endogenous variables of the model, as before foundation firms do not belong to any state of nature. Therefore, these $m$ variables are included in the column vector $k_{i t-1}=\left(k_{1 i t-1}, \ldots, k_{m i t-1}\right)^{T} \in \mathbb{R}^{m}$ that cannot influence firms' probability of accessing external funds at $t=t_{i}^{E}$. Accordingly, in the specification of the model these independent variables are multiplied by $1-$ Dseed $_{i t}$. Besides, we define another set of $h$ explanatory variables included in vector $z_{i t}=\left(z_{1 i t}, \ldots, z_{\text {hit }}\right)^{T} \in \mathbb{R}^{h}$ : these vector includes both non-lagged time-varying independent variables (e.g. firm age, number of managers, macroeconomic conditions) and time-unvarying covariates (e.g. location- and industry-specific). ${ }^{6}$

Hence for a YIC that was not financed by a VC investor and did not access any GG bank loan (i.e. it starts from state 0), the latent regression system is:

$$
\begin{aligned}
& y_{i t}^{* A}=\alpha_{A} z_{i t}+\beta_{A} k_{i t-1}\left(1-\text { Dseed }_{i t}\right)+\varepsilon_{i t}^{A}, \\
& y_{i t}^{* B}=\alpha_{B} z_{i t}+\beta_{B} k_{i t-1}\left(1-\text { Dseed }_{i t}\right)+\varepsilon_{i t}^{B} .
\end{aligned}
$$

Where $\alpha_{A}$ and $\alpha_{B}$ are row vectors of coefficients associated to the time-varying and timeunvarying covariates, and $\beta_{A}$ and $\beta_{B}$ are row vectors of the regression coefficients corresponding to the lagged time-varying variables.

In a multivariate probit setting the standardized bivariate normal distribution for error terms is assumed, for $\left(\varepsilon_{i t}^{A}, \varepsilon_{i t}^{B}\right)$ :

$$
\left(\begin{array}{c}
\varepsilon_{i t}^{A} \\
\varepsilon_{i t}^{B}
\end{array}\right) \sim \operatorname{iidN}\left(\left(\begin{array}{l}
0 \\
0
\end{array}\right),\left(\begin{array}{ll}
1 & \rho \\
\rho & 1
\end{array}\right)\right)
$$

where $\rho$ represents the correlation between the error terms of the latent regressions. Accordingly with Mosconi and Seri (2006), in order to maximize the likelihood function without using constraints, the correlation is reparametrized in a logit-type functional form:

$$
\rho=\frac{\exp \left(\gamma_{0}\right)-1}{\exp \left(\gamma_{0}\right)+1}
$$

where $\gamma_{0}$ is the coefficient associated with the correlation term, before the z-transformation.

\footnotetext{
${ }^{6}$ For this second set of covariates - the time-unvarying - we assume $z_{i t}=z_{i} \forall t$.
} 
It follows that the probability of moving to state 1 or 2 or 3 at year $t$, provided that firm $i$ is in state 0 at year $t-1$, can be modelled through a bivariate survival model. This means that:

$$
P\left\{y_{i t} \mid y_{i t-1}=[0,0]\right\}=\Phi_{2}\left(\left(\begin{array}{c}
\alpha_{A} z_{i t}+\beta_{A} k_{i t-1}\left(1-\text { Dseed }_{i t}\right) \\
\alpha_{B} z_{i t}+\beta_{B} k_{i t-1}\left(1-\text { Dseed }_{i t}\right)
\end{array}\right) ; 0,\left(\begin{array}{cc}
1 & \rho \\
\rho & 1
\end{array}\right)\right) .
$$

Where $y_{i t}$ and $y_{i t-1}$ represent the states reached by the firm respectively at year $t$ and $t-1$. $\Phi_{2}(\cdot ; \mu, \Sigma)$ denotes the bivariate normal distribution, with mean $\mu$ and covariance matrix $\Sigma$. For a YIC which has obtained VC funds at year t-1 (i.e. it is in state 1), the only possible transition at year $t$ is the one that brings the firm to get also access to the GG bank loan program (i.e. from state 1 to state 3 ). Hence, the underlying latent regression for the access to the GG bank loan after obtaining a VC investment is:

$$
y_{i t}^{* B}=\alpha_{B} z_{i t}+\beta_{B} k_{i t-1}\left(1-\text { Dseed }_{i t}\right)+\beta_{A \rightarrow B} y_{i t-1}^{A}\left(1-\text { Dseed }_{i t}\right)+\varepsilon_{i t}^{B},
$$

which gives rise to the univariate probit model:

$$
P\left\{y_{i t}^{B} \mid y_{i t-1}=[1,0]\right\}=\Phi_{1}\left(\alpha_{B} z_{i t}+\beta_{B} k_{i t-1}\left(1-\text { Dseed }_{i t}\right)+\beta_{A \rightarrow B} y_{i t-1}^{A}(1-\right.
$$

Dseed $\left.\left._{i t}\right) ; 0,1\right)$.

Where $\Phi_{1}$ represents the standard normal distribution with mean 0 and standard deviation 1.

Similarly, for transiting from state 2 to state 3, as defined by the latent regression model, we will have:

$$
y_{i t}^{* A}=\alpha_{A} z_{i t}+\beta_{A} k_{i t-1}\left(1-\text { Dseed }_{i t}\right)+\beta_{B \rightarrow A} y_{i t-1}^{B}\left(1-\text { Dseed }_{i t}\right)+\varepsilon_{i t}^{A},
$$

which leads the univariate probit model to be formulated as follows:

$$
P\left\{y_{i t}^{A} \mid y_{i t-1}=[0,1]\right\}=\Phi_{1}\left(\alpha_{A} z_{i t}+\beta_{A} k_{i t-1}\left(1-\operatorname{Dseed}_{i t}\right)+\beta_{B \rightarrow A} y_{i t-1}^{B}(1-\right.
$$

Dseed $\left.\left._{i t}\right) ; 0,1\right)$.

The model is estimated through the maximum likelihood method. Parameter $\beta_{B \rightarrow A}\left(\beta_{A \rightarrow B}\right)$ captures the increase in the probability of getting a VC (GG bank loan) once a firm has obtained a GG bank loan (VC). Therefore, coefficients $\beta_{A \rightarrow B}$ and $\beta_{B \rightarrow A}$ offer an immediate test of the Granger causality relationship related to the likelihood for the YICs to access GG bank loan 
once backed by a VC (and vice versa). The Granger non causality condition is tested in a single step, using the Wald Test. Then, the hypothesis that the simultaneous access to VC financing and GG bank loan is more likely to occur than the recourse to each source of financing in isolation is verified through a Wald test for the parameter $\gamma_{0}$ (Table 4), which drives the correlation coefficient $\rho$ (see Mosconi and Seri 2006, p. 403) introduced in Equation 4.

\subsection{Variables}

The investigation about the probability for the Italian YICs to access subsidized VC and GG bank loans is carried out using a large set of covariates underpinned by the scientific literature discussed in Section 2. Variables can be grouped into four different categories: firm-specific, location-specific, macroeconomic-specific and sector-specific variables (see Table 2).

\section{[Insert Table 2]}

Firm-specific variables are related to the company characteristics, taking into account age, size, financial structure and assets’ profitability. According to Mina et al. (2013) and Beck and Demigurc-Kunt (2006), company age and size are important determinants of firms' access to external finance, since younger and smaller ventures are considered riskier than more mature and larger counterparts. In particular, startup age is captured by both the variable Dseed $_{t}$, a dummy that identifies firms in their foundation year, and by the variable Age $_{t}$ which measures firm age at year $t .^{7}$ To describe the size of the YIC, we make use of the number of employees at year $t-1$ (Employees Em $_{1}$. On the one hand, venture capital investors are naturally inclined to invest into seed and startup projects in an early phase (Barry, 1994), but on the other hand they do not consider too small entrepreneurial initiatives (Gompers and Lerner, 2004). Banks are

\footnotetext{
${ }^{7}$ Note that the maximum value for the variable $A g e_{t}$ exceeds 5 years and it is equal to 9 . In fact, the retroactive nature of the law allows for companies incorporated before 2012 to have the status of YIC for a reduced time span ( 5 years or less). So, the period of investigation goes even beyond the time window envisaged by the Law no. 221/2012. This represents an advantage in our context since it enables to better investigate the presence of possible interrelationships between the two financing modes, and in particular, to verify whether YICs subsidized by a GG bank loan could access venture capital investments even beyond the subsidization period.
} 
usually inclined to deny credit to younger businesses, but their attitude can be different when the loan is partially guaranteed, for example to gain new customers (Binks and Ennew, 1997). As a further variable for size, we also use the natural logarithm of the total assets owned by the company (LnTotAsset $t-1$ ) (Bougheas et al., 2006). ${ }^{8}$ In this respect, we expect a positive impact of the value of company assets on the probability to access the two instruments, especially GG bank loans: banks, in fact, should be particularly sensitive to the quality of the assets which may serve as collateral in case of firm default (Ueda, 2004; Beck and Demirguc-Kunt, 2006). ${ }^{9}$

Then, following Hellmann and Puri (2002), and their argument about the importance of professionalization of startups as a driver criterion for venture capitalists, we introduce the variable $N \_$Manager ${ }_{t}$ counting shareholders and managers who have an "active” role in the governance of the startup, at year $t .^{10}$ Accordingly, we expect a positive impact of this variable on YICs’ access to VC (Mason and Stark, 2004).

Leverage $_{t-1}$, defined as the ratio of the financial debt to total assets at year $t-1$, captures YIC’s financial structure. Baum and Silverman (2004) argue that VCs invest in more leveraged firms, while Mina et al. (2013) find that less leveraged firms are preferred. The company profitability is a further variable examined by investors (Mina et al. 2013); yet both equity investors and banks will consider prospect profitability, more than current profitability. Therefore, on a priori ground, we do not expect any strong association in this case. As a proxy of the startup profitability and efficiency of the investments, we use the ROA (return on assets), that is the

\footnotetext{
${ }^{8}$ The correlation between Employees $t_{t-1}$ and LnTotAsset $_{t-1}$ is equal to 0.309. To avoid any possible concern related to multicollinearity, the two variables are entered into the regressions both separately and jointly, always revealing a similar impact both in economics and statistical terms. The correlation matrix of all explanatory variables is available in appendix, Table A1.

${ }^{9}$ We must remember that the government grants the guarantee only on a portion of the bank loan. Therefore, the lender faces the credit risk on the residual part.

${ }^{10}$ This firm-specific variable is introduced into the model specification considering the value at time $t$. However, note that introducing into model specification this variable at time $t-1$ leaves our findings totally unaltered (results available upon request from the authors).
} 
ratio between the operating margin and the total assets of the YIC at year $t-1 .{ }^{11}$ The $R O A_{t-1}$ (the ROA lagged at year t-1) figure gives investors an idea of how effective the company is in converting the money it invests into net income (Díaz-Díaz et al., 2008; Robb and Watson, 2012; Robinson, 1999; Rothaermel, 2001).

Turning to the location-specific group, four explanatory variables are gathered. The goal of geographical variables is to highlight the effect of the regional (at NUTS 2 level) economic and entrepreneurial ecosystem in which firms are embedded on the YICs' probability to take advantage of the two different policy measures here investigated. A number of studies highlight the importance of the heterogeneity of the local environment (e.g. wealth distribution, infrastructure availability, industrial clusters, local social capital), in determining access to finance by entrepreneurial ventures (Fritsch and Noseleit, 2013; Giudici et al., 2018). DSouth is a dummy variable which assumes value 1 for companies located in the south of Italy, where this area turns out to be historically the least economically developed of the country. In this respect, it is interesting to investigate if the two investigated policy measures help YICs located in this specific disadvantaged area to lessen their financial constraints more than YICs located elsewhere. In the same vein, we introduce into the model three other variables. Industrial Intensity is the ratio between the number of active firms in the focal region over the number of hundreds of residents, in the year 2012; Value Added computes, in percentage terms, the regional contribution to the national value added in the year 2011; while Infrastructure is a composed index referring to the year 2011 and capturing the regional infrastructural and economic endowment in terms of transportation and logistics facilities, telecommunication networks development and capillarity of banking services.

\footnotetext{
${ }^{11}$ To avoid problems with results dominated by a few outliers, we winsorize the variable by cutting the $0.5 \%$ of the left and right tails of the $R O A_{t-1}$ distribution.
} 
Finally, we include a set of industry and business cycle control variables. Among others, Da Rin et al. (2006) underline the importance of controlling for macroeconomic factors in explaining firms' access to finance. In detail, we use dummy variables to control for the yearly national deficit on the overall GDP (Deficit/GDP ), for the yearly growth of the real GDP $(G D P G r o w t h)$ and for the industry in which firms operate (Manufacturing, R\&D, Software and General Services).

Table 3 illustrates the descriptive statistics for the explanatory variables. The logarithm of the total assets ranges from 0 to 16.380 , thus indicating that the sample comprises both YICs just established and companies with some activities in place. The leverage ratio is also varying; we have companies with virtually no debt and companies that borrowed more consistently. ${ }^{12}$ Not surprisingly, also the value of the return on assets ratio is dispersed, since both the operating margin and the total value of assets for many companies are very low, thus leading to very low or very high values of their performance ratios.

\section{[Insert Table 3]}

\section{Empirical analysis}

\subsection{Main results}

The results of the econometric analysis are exposed in Table $4 .{ }^{13}$ In the upper part of the Table we analyse first transitions: in the first column the estimates are related to the firms' likelihood to access VC investments $\left(y^{A}\right)$ and in the second column estimates refer to YIC's access to GG bank loans $\left(y^{B}\right)$. The lower part of the Table reports the results on the second transitions.

\section{[Insert Table 4]}

\footnotetext{
${ }^{12}$ In some cases the value is larger than 1 because of the relevant losses carried forward by the companies, that sometimes exceed the book value of the equity capital.

${ }^{13}$ We estimate the econometric models using OX Professional (Doornik, 1999).
} 


\subsubsection{First transitions: segmentation vs similarity}

Overall, the results point to the presence of relevant differences among YICs in terms of access to the two different financial sources and underlying policy interventions. In order to confirm the presence of segmentation between YICs, specific z-tests are run between the coefficients of the two equations, with the aim to test their differences (Brame et al., 1998; Paternoster et al., 1998). The null hypothesis that the coefficient of a variable for the VC equation is equal to the corresponding coefficient of the same variable in the GG equation is rejected, at the $1 \%$ level, for almost all the firm-specific regressors. These results speak in favour of the Task segmentation hypothesis.

More specifically, beside the accumulation point at the founding year which is positive and significant for both typologies of subsidized financing forms (but stronger for GG bank loans, see the coefficients of the variable Dseed $_{t}$ and the related z-test), the estimated coefficient of Age $_{t}$ is negative and statistically significant (at 1\%) on the probability to access GG bank loans, while it turns out to be statistically negligible for what concerns the YIC's probability to access VC funds. Thus, the result highlights that GG bank loans show a relatively higher propensity than VC investments to flow towards very early stage companies. Similarly, Employeest-1 has a negative and significant impact on the GG equation (at 5\% level), while it turns positive but not statistically significant for the VC equation. In other words, small-sized YICs, in terms of employees, find easier access to GG bank loans than VC investments (notwithstanding the fiscal incentives at work). The results point to a sort of 'institutional division of labour' between the two policy measures under investigation.

But differences between the two estimated equations include also other determinants. LnTotAsset $t_{-1}$ has a positive impact on both subsidized VC investments and GG bank loans, but the coefficient is larger for the latter than for the former, their difference being statistically significant at $1 \%$ level. In this case, while both financing types do not appear to flow towards 
largely undercapitalized YICs, the result also suggests the relevance at the banks' eyes of the collateral value embodied in total assets for securing the loan (notwithstanding the presence of the partial government guarantee).

The variable $N \_$Manager ${ }_{t}$ has a positive and statistically significant impact on VC financing (at 1\%) but it is not statistically significant in the GG bank loans equation. These findings confirm the particular attention to the team and managerial professionalization paid by equity investors compared to bank lenders of the firm. Overall, the findings suggest that the two types of investors target different types of YICs.

The variables Leverage $_{t-1}$ has a negligible impact on both regressions, indicating the absence of any statistical connection between the likelihood to receive VC funds or GG bank loans and the YIC current financial structure. On the other side, the variable $R O A_{t-1}$ has a negative impact both on VC (at 5\%) and GG equations (at 10\%). This evidence shows how the short-term return for early-stage startups is not considered a key decision driver for the investors; on the contrary, costs and investments are positively evaluated as to finance future growth and survival.

Regarding location-specific variables, the coefficient of the variable DSouth is statistically insignificant for both subsidized VC and GG bank loan equations. On the other side, the variables Industrial Intensity and Value Added exhibit a positive and significant impact on the YIC’s probability to obtain a GG bank loan (respectively at 10\% and 5\% levels), while only Value Added has a positive and statistically significant effect for what concerns the probability to obtain a VC investment. Overall, there is no evidence that the two policy measures increase access to finance for YICs in less developed regions, compared to the rest of the country.

Interestingly enough since it points to a notable difference, while access by YICs to GG bank loans turns out to be pro-cyclical, the reverse applies to VC. In fact, both variables

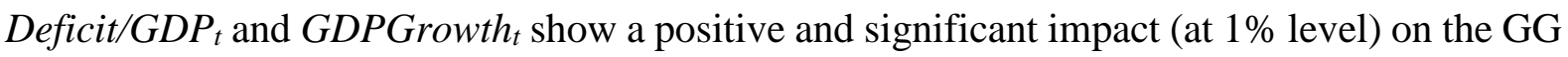

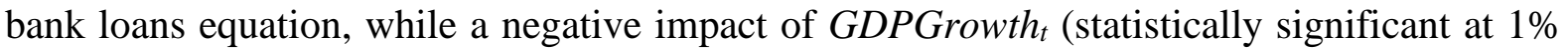


level) emerges in the VC regression. Looking at the industry dummies, the higher probability to receive a VC investment is found for Software YICs, while firms active in Manufacturing show a greater propensity to access GG bank loans than YICs active in other sectors.

\subsubsection{Substitutability vs Complementarity}

Results related to second transitions are displayed in the lower part of Table 4. While the coefficient $\beta_{B \rightarrow A}$ is positive but statistically negligible, the coefficient $\beta_{A \rightarrow B}$ is negative and statistically significant (at 5\% level). This result points to the presence of a substitution effect: once backed by a VC, a YIC is less likely than before to access a GG bank loan. This finding highlights how the investment in equity made by a VC reduces the likelihood by the startup to apply for a Government-guaranteed bank loan. Finally, simultaneous obtainment of both forms of financing is equally likely than obtaining each source of financing in isolation as testified by the large statistical insignificance of the parameter $\gamma_{0}$.

To sum up, what stands out from the empirical analysis is that the two policy measures sustain rather different typologies of YICs, with different characteristics. Once a YIC receives support from VC, this further decreases its likelihood to obtain a GG bank loan. Thus, the picture that emerges is a kind of Task segmentation between the two policy measures. In the following, we investigate whether this effect is robust to different model specifications and check and provide additional evidence on the topic.

\subsection{Robustness checks and augmented models}

In order to gauge the robustness of our findings, we test them by running distinct sub-sample analyses, adopting different specifications and implementing alternative methodologies. The results of z-tests in these new settings are very similar to the ones already exposed and overall, they deliver the same picture. ${ }^{14}$

\subsubsection{Industry segmentation}

\footnotetext{
14 The z-test results are available upon request.
} 
Results from Table 4 highlights the presence of a Task segmentation effect between the different policy measures. In this section we explore whether industry heterogeneity may determine interesting differences and nuances to this global picture. In fact, strategies by innovative startups can be highly idiosyncratic with respect to the sector of operations and this may translate in different financing needs and opportunities for YICs operating in different industries (Hall et al., 2000; Johnsen and McMahon, 2005). Our enquire is to some extent limited by the small number of second transitions available (e.g. as reported in Table 1, only 48 out of 2,526 YICs have obtained both VCs and GG bank loans) which makes impossible the estimation of sector-specific dynamic bivariate survival models using a fine-grained industry classification. We tackle this limitation as follows. We re-aggregate the four-pronged industry classification used in the main analysis (i.e. Manufacturing, R\&D, Software and General Services sectors) by forming two industry macro-categories, e.g. ManufacturingR\&D sector and Software-Services sector. Allegedly we run the dynamic bivariate survival model in the two sub-samples identified. Results of this analysis are reported in Table 5. Then, we also run a series of dynamic bivariate probit analyses in the four original industries to verify that first transitions do not greatly differ within each macro-category. Overall, apart from a loss of statistical significance of some coefficients, the picture of Task segmentation effect is confirmed and our further check does not reveal the presence of more dramatic cross-sectorial differences than those already highlighted in the previous Section.

Focusing on the most notable differences with the full sample, for the Software-Services sector sub-sample, the effect of the number of Employees at $t-1$ on the probability to access GG bank loans is now statistically insignificant, while it is negative and significant for the whole sample (at the $5 \%$ level, see Table 4) and for the Manufacturing-R\&D sub-sample (at the $1 \%$ level). Moreover, while the coefficient of $R O A_{t-1}$ is still negative in the VC equation for both the mentioned groups, it now turns out to be statistically negligible in the GG loan equation for 
the Software-Services sub-sample. Concerning the analysis of second transitions, the coefficient $\beta_{A \rightarrow B}$, associated to the effect of previous access to an equity investment on the access to a GG bank loan ( $V C \rightarrow G G)$, remains negative and statistically significant at $5 \%$ for the Services-Software sector sub-sample, while it remains negative but loses some statistical significance in the Manufacturing-R\&D sub-sample.

Overall, the findings reveal the presence of some interesting nuances across different sectors. But these differences appear limited in numbers and, for what most matters from our perspective, these findings confirm the general picture and bring support to the Task segmentation effect.

\section{[Insert Table 5]}

\subsubsection{Human capital variables}

Starting from the original sample of 2,526 YICs and focusing on the sectors with the higher number of companies in the two macro-sector previously identified (i.e., the Software and Manufacturing industries), we also verify whether our findings are robust to an augmented model specification which also includes independent variables capturing the human capital of the YICs' entrepreneurial teams. In fact, there is a conspicuous body of literature which highlights how entrepreneurs' human capital is usually an important driver of VCs' target choice (e.g. Muzyka et al., 1996; Zacharakis and Meyer, 2000; Baum and Silverman, 2004). We aim at verifying if the inclusion of these characteristics may change the findings already exposed and, eventually, in which direction they do so. To this extent, we were able to collect manually information on the educational background and work experience of 2,256 entrepreneurs of 1,072 YICs. ${ }^{15}$ Data were retrieved by combining the use of the Telemaco

\footnotetext{
${ }^{15} \chi^{2}$ tests show that there are no statistically significant differences between the distribution of this sample of 1,072 YICs and the corresponding distributions of the large sample from which it was drawn. In particular, the small one is very similar to the large one under all the financials indicators/company characteristics and presence of external investors. Results are available upon request from the authors.
} 
database jointly with the professional social network LinkedIn through a Premium access. ${ }^{16}$ The human capital data are related to the education and work experience of entrepreneurs. More specifically, the former includes information about the education degrees (bachelor, master and $\mathrm{PhD}$ ) and the study fields (technical/scientific or economic). The latter includes information about the generic pre-entry work experience of the entrepreneur, the pre-entry work experience that each entrepreneur gained in the sector of operation of the startup and the pre-entry managerial experience. More specifically, Economic Education is the average of the number of years of the founders' economic and/or managerial education at graduate and post-graduate level. Technical Education is the corresponding variable in terms of scientific and/or technical subjects. Managerial Experience measures the average number of years of the entrepreneurs' managerial pre-entry professional experience. Sector Work Experience and Generic Work Experience measure the average years of founders' work experience in the same sector and in other sectors of the startup before foundation, respectively. Definition of these variables and their descriptive statistics are provided in the dedicated Appendix (see Table A2 and Table A3).

We run the main econometric model with an augmented specification including these variables and the results are exposed in Table 6. Notably, entrepreneurs' human capital is found to scarcely affect YIC's access to (subsidized) VC, where only Managerial Experience is found to positively and significantly (at 5\% level) impact the YIC's probability to obtain an equity investment. ${ }^{17}$ Other results related to the first transitions in the VC equation are rather similar to those exposed in Table 4. Looking at the GG bank loan equation, interesting results

\footnotetext{
${ }^{16}$ The use of information gathered from professional social networks like LinkedIn in scientific studies has become common in the entrepreneurship literature (Gloor et al., 2011; Weber and Jung, 2015; De Cleyn et al., 2015; Ge et al., 2016; Giudici et al., 2018).

${ }^{17}$ We check for potential multicollinearity concerns through Variance Inflation Factor (VIF) tests, considering both only founders' human capital variables and the whole explanatory variables. The results of the tests confirm the absence of any serious problem in this respect. We run also alternative regressions, including one single variable related to human capital at each stage, and the results reported in Table 6 are confirmed. These results are available upon request to the authors.
} 
characterize the variables Economic Education, Sector Work Experience and Generic Work Experience. They show negative and significant (respectively at the $10 \%$ level only for the former two and at the $5 \%$ for the latter) coefficients. As described in the existing literature, our results confirm the secondary importance of the entrepreneurial team to the bankers, highlighting that the lending decisions are dominated by financial factors. Considering that the characteristics of the founding team are an important determinant of YICs' assets, we interpret the results as another evidence in favour of segmentation of YICs for what concerns the two type of investors (and the two underlying policy mechanisms). Considering the control variables, macro-economic specific determinants lose significance in the GG loan equation; the number of managers becomes positively correlated, and the location in the South of Italy negatively correlated, but the significance levels are very low (10\%). The return on assets turns to be insignificant.

As to the second transitions, it is quite interesting to observe that the coefficient $\beta_{A \rightarrow B}$ is still negative and statistically significant (at 5\% level) as in Table 4. In other words, it is reinforced the result that once received a VC investment, a YIC becomes even less likely than before to access the other form of subsidized financing, i.e. GG bank loans.

\section{[Insert Table 6]}

\subsubsection{Local entrepreneurial and financial eco-system}

In order to better investigate the effects of the specific geographical location on YICs' probability to access the two financing mechanisms, we also enlarge our model specification by adding two specific geographical-related covariates, Incubators and VC Investment 1 . The former is the number of incubators and permanent accelerator programs (source: Italian Chambers of Commerce) existing at regional level (NUTS2), where we distinguish the number of those active before and after 2012; the latter is the lagged total amount of VC investments per region per year (source: AIFI, the Italian Association of Private Equity and Venture Capital 
investors). Business incubators constitute a specific institution designed to support new ventures by providing to the tenant companies several facilities, from workspace to management and knowledge support (Colombo and Delmastro, 2002; Peters et al., 2004; Aerts at al., 2007). Then, VCs are 'local' investors, in the sense that most investees are often located nearby VCs' headquarters (Gompers and Lerner, 2004; VICO, 2011; Lutz et al., 2013). Therefore, both variables capture two salient characteristics of the entrepreneurial ecosystem in which YICs operate that may interfere with the investigated dynamics. The results are reported in Table 7. The coefficient of Incubators is found to be positive and significantly correlated with the access to subsidized VC investments. The result highlights that incubators may ease the information flow and create direct connections between YICs and investors. They are often considered as a source of deal flow from venture capitalists and business angels (Gompers and Lerner, 2004).

The coefficient of VC Investment $t-1$ is negative (at the $5 \%$ level) in the VC equation. The evidence may be interpretable through a 'saturation' effect: in thin markets, if the demand for capital at the local level is given, an investment from venture capitalists will reduce the probability of new deals in the following year in the same region (for similar findings in the Italian context see Bertoni et al., 2019). Another possible explanation could be the VCs' objective to diversify investment risks throughout different regions. ${ }^{18}$

The coefficients of Incubators and VC Investment $t_{-1}$ are found to be statistically insignificant in the GG bank loan equation; the vivacity of the local startup and venture capital ecosystem does not seem to influence bank borrowing. Looking at the second transitions, the results

\footnotetext{
${ }^{18}$ Looking at aggregate statistics the two reasons do not appear as mutually exclusive and, indeed, can be both at work. Over the year 2014, the total amount of government subsidized VC was estimated to be equal to about $€$ 26.3 million (Source: Ministry of Economic Development, 2016) vs. about $€ 43$ million of total VC activity towards early stage financing (source: AIFI). Interestingly, the North region attracted $73.3 \%$ of government subsidized VC, while the percentage of general VC investments in the same region was estimated to be around $90 \%$. The combination of these statistics suggest from one side that the government subsidized VC constituted a conspicuous part of the total VC industry; and on the other side, the subsidized VC flowed relatively more intensively towards the Centre and the South of Italy.
} 
confirm the evidence highlighted in Table 4, confirming the presence of a Task segmentation effect. The significance of the coefficients of the other variables are virtually unchanged, compared to Table 4.

\section{[Insert Table 7]}

\subsubsection{Lagged variables}

Additionally, we address the possible concern that the information loss associated with the use of lagged independent variables, despite their operationalization through Equation (1) and the multiplication with 1-Dseed ${ }_{i t}$, could undermine the explanatory power of such covariates. To this purpose, we run again the model by using all time-varying covariates at year $t$. Results are exposed in Table 8.

\section{[Insert Table 8]}

The most sensitive change in respect to the results shown in Table 4 involves the Employees $t_{t}$ variable. Using the total amount of employees per company in the same year of analysis, the coefficient becomes statistical insignificant in the GG bank loans equation. But apart from this change, no major modifications are brought to our findings.

\subsubsection{Seemingly unrelated bivariate probit model}

Finally, we also use one alternative methodology, specifically a seemingly unrelated bivariate probit model, in order to further assess the robustness of our findings (Mina et al., 2013). Compared to the dynamic bivariate survival model, this approach has been originally intended to analyse static processes.

As shown in Table 9, the results are similar to those highlighted in the previous sets of regressions and, above all, they confirm the Task segmentation effect. ${ }^{19}$ Furthermore, the results

\footnotetext{
${ }^{19}$ We also check through a series of Wald tests the null hypothesis of equality of the coefficients of each independent variable across the two equations of the seemingly unrelated bivariate probit model by adapting the procedure reported in Gimmon and Levie (2010). The results are totally in line with the z-tests run for the dynamic bivariate survival model (see Table 4), and they further reinforce the Task segmentation effect: we can now reject the null hypothesis of equality also for the coefficients associated with the variables Leveraget-1 and $R O A_{t-1}$ at the $1 \%$ level, and for Infrastructure and $R \& D$ sector at the 5\% level (results are available upon request) .
} 
highlight that the correlation coefficient between the error terms of the two equations is not statistically significant (looking at the bivariate probit regression, $\rho$ is equal to 0.089 , chisquare $(1)=1.020, \mathrm{p}$-value $=0.3124)$, featuring that non-modelled unobserved heterogeneity does not seem to interfere significantly with the investigated dynamics.

\section{[Insert Table 9]}

\subsection{Additional evidence}

Finally, having proved the robustness of our findings related to the Task segmentation effect, we hereby briefly explore two interesting aspects related to the dynamics at stake. ${ }^{20}$

First, we investigate which characteristics of banks and VCs are associated to a greater attitude in taking advantage of the underlying policy mechanisms and provide funds to YICs, and in particular we explore whether larger financial operators were more prone than smaller ones. To this purpose, a new hand-collected longitudinal database has been built, starting from the list of banks and professional venture capitalists that invested in the YICs included in our dataset. We have thus identified 101 banks and 116 VCs and for all of them we have manually counted the total annual number of $i$ ) loans granted through the GG measure (418) and ii) VC investments (276), during the sample period (see Table 10).

[Insert Table 10]

Based on this additional collection of data, we perform the following econometric analysis, by running two different regressions. More specifically, we introduce two dependent variables (i) Loans ${ }_{t}$ and (ii) VC Investments $s_{t}$, namely the number of GG loans and equity investments made by the investors, during year $t$. The independent variable for equation (i) is the bank size, measured by the logarithm of consolidated total assets at the beginning of year $t$, i.e. LnConsAsset $_{\text {( }}$ Source: MBRES - Ufficio Studi Mediobanca S.p.A.). While the independent variable of interest in equation (ii) is the VC fund size, measured by the log of the assets under

\footnotetext{
${ }^{20}$ We thank an anonymous reviewer for raising these interesting issues.
} 
management at the beginning of year $t \operatorname{LnAUM}_{t}$ (Source: CrunchBase, VCs' balance sheets and websites). Then, we include different control variables in both equations. For what concerns banks, the dummy variable International Branch takes value 1 for foreign banks which have a branch in Italy. Foreign banks could be driven by different objectives, compared to national incumbents, or could rely on the experience built in more important markets, like the US or UK (Giudici and Roosenboom, 2004). In the same vein, Local Bank is a dummy variable that identifies regional banks (that could benefit from lower information asymmetry and proximity with the YIC; see Binks and Ennew, 1997) and finally, the dummy Startup Program is equal to 1 if the bank runs a specific startup acceleration program. Turning to the VC equation, we include the dummy variable Foreign Headquarter which takes the value of 1 for foreign VC investors. We run random effects panel data regressions whose results are exposed in Table 11. The results are also corroborated and largely confirmed by two further analyses: a) the use of weights to check whether the unbalanced nature of the dataset could drive some findings; b) an OLS cross-sectional analysis limited at one single year (2016), where the two dependent variables are defined as the cumulated sum of deals over time, from 2009. We see that larger banks have been more eager to invest in YICs, while conversely there is no 'size effect' for what concerns VCs. Interestingly, the coefficient of the Startup Program variable is found to be positive and statistically significant (at 1\%) on the number of granted loans, pointing to the fact that credit backed by government guarantees is more likely to be granted by banks institutionally oriented towards the financing of YICs. As to the international breadth of operations, this does not seem to greatly affect either the number of loans granted or VC investments. In particular, controlling for the size of the VC, foreign affiliated VCs have ceteris paribus contributed less than the Italian counterparts to the 276 sample VC deals (as a matter of fact we counted 30 foreign VCs out of 116, which implemented 41 out of the 276 investments tracked in this research). 
As a second interesting aspect, we explore how the two (policy subsidized) financial measures have impacted YICs’ operating performance. Relying on an extensive literature on entrepreneurial performances (Delmar et al., 2003), we focus on both sales and employees growth dynamics. Specifically, we collected such data (source: AIDA - Bureau van Dijk) all over the years 2009-2015, and, taking advantage of the (unbalanced) panel-data structure of our dataset, we build at the company-level two performance variables: a) LnSales ${ }_{i t}$ which is the logarithm of the total annual sales of firm $i$ during year $t^{21}$ and b) TotEmployees $s_{i t}$, the number of employees reported by firm $i$ at the end of year $t$. Following the consolidated empirical literature on startup performances (e.g. Colombo and Grilli, 2005; 2010), "the vector of independent variables includes the age of the firm, thus to make the dependent variable an indicator of the average yearly absolute [sales or employees] growth in the period in which a firm is observed” (Colombo and Grilli, 2005, pp. 804-805). Since the aim of the analysis is to ascertain the effect of the (policy subsidized) external financial resources on firms' performance, two time-varying step dummies are included as main independent variables: lagged venture capital investment, $V C_{t-1}$, and lagged access to a Government- guaranteed bank loan, $G G_{t-1}$. The binary variables are equal to 1 if the sample YIC $i$ received venture capital financing, or alternatively a GG bank loan, during year $t$. The model specification is completed by a series of control variables already defined in Table 2 . We run this performance analysis using a panel data random effects model. Results are presented in Table 12. They highlight that VC is undoubtedly a driver of growth performances (both in terms of sales and employees), in line with the most recent empirical literature in the field (e.g. Bertoni et al., 2011; Grilli and Murtinu, 2014); while the effect of GG bank loans is positive and statistically significant only

\footnotetext{
${ }^{21}$ The logarithmic transformation of sales is generally used in studies on firm growth to take into account possible outliers. It is worthwhile to note that in our case this choice does not sensibly affect the results.
} 
for what concerns employee growth and it is less neat from a statistical point of view for what concerns sales. This analysis is corroborated by further checks. In particular, results are unchanged once performance variables in levels are transformed in logarithmic growth variables and when a dynamic specification is used and the resulting model estimated through a GMM-SYS estimator, which takes into account the endogenous nature of the lagged dependent variable and (potentially) of the two main independent variables of interest, i.e. $V C_{i t-}$ 1, and $G G_{\text {it-1 }}$. Despite of the fact that all these analyses point to the same direction, we still deem this investigation as only short-term oriented, given the unavoidable limited distance in time eventually occurring between investments and performances. ${ }^{22}$

[Insert Table 12]

\section{Discussion and conclusions}

\subsection{Summary of results}

Both academic scholars and policy makers agree on the importance for an economic system to nurture the creation and sustainment of YICs and startups. YICs are deemed to be capable to challenge existing technological paradigms and to ensure a high degree of dynamic efficiency in modern economies. Accordingly, they are increasingly becoming a specific object of study for academics (see Schneider and Veugelers, 2010; Czarnitzki and Delanote, 2013) and an explicit target for industrial policies by policy makers, especially in the European context (see for EC-DG ENTR, 2009, for an overview). This typology of firms is in fact reputed to suffer from important capital market imperfections (see Carpenter and Petersen, 2002) which may prevent YICs from exerting their beneficial effects into markets. Thus, while general consensus exists on the need for public intervention devoted to alleviating YICs' financial

\footnotetext{
${ }^{22}$ Therefore, while acknowledging the interest of these preliminary findings, at the same time we recommend caution in their emphasis. Future research endeavours will be needed in this respect by embracing a longer time perspective as soon as the accounting data of the sampled YICs will be released in the future.
} 
constraints, much less agreement is traceable on the most effective policy mechanisms that are capable to accomplish the task. Following the entrepreneurial finance theory, venture capital (VC) investors are considered the preferred financing mode for this typology of firms (Gompers and Lerner, 2001; Carpenter and Petersen, 2002). Conversely, contrary to the conventional wisdom, other studies argue that young and risky new ventures may choose debt contracts instead of equity since hazardous but large returns are of relatively more value for a loan-financed firm (Chen et al., 2010; Schäfer et al., 2004).

Several recent studies have analysed, especially from the perspective of the demand for outside finance, the way to foster investments for young and innovative companies but it remains rather underexplored the evaluation of possible interdependencies with different policy measures aiming at easing YIC’s access to external financing sources.

This study exploits the Italian Startup Act (Law no. 221/2012) to shed light on this key issue. In this case, in fact, YICs are equally exposed at the same time and in the same institutional context to two specific policy measures which aim at alleviating their financial constraints. The first measure envisages fiscal incentives for equity investors (i.e. venture capital), while the second gives privileged access for YICs to a Government-guaranteed (GG) bank loan program. Therefore, through the collection of a hand-collected dataset on 2,526 Italian YICs and the means of a dynamic bivariate survival model (Mosconi and Seri, 2006), we first investigate whether firms accessing one instrument differ along a series of characteristics from counterparts accessing the other one. Secondly, we dig into the mutual interrelationships existing between the two policy measures. Our first important result is that the two mechanisms appear to be functional to YICs with a different profile. Specifically, YICs obtaining GG bank loans appear relatively younger, are managed by less executives and employ less people than those YICs invested by (subsidized) VC. The latter are endowed with a lower asset value, and are more active in the Software business (and less in Manufacturing). 
In other words, a sort of 'institutional division of labour' seems to be in place between the two measures, with each instrument financing a distinct type of YIC. As expected, in their investment conducts VCs appear to diverge substantially from bankers, and the policy intervention does not change radically the selection process. Secondly, once received support from one measure, a clear substitutability effect emerges towards the other instrument. There is a statistically significant evidence that once received a VC investment, a YIC becomes even less likely than before to access a GG bank loan. In that respect, our findings support a Task segmentation effect between the two policy mechanisms: they target (and serve the needs) of different YICs, and once obtained a type of financing is unlikely that the supported firms will access the other form.

\subsection{Future researches and data limitations}

Some unavoidable limitations of our study open interesting avenues for future research. First, whether the 'equilibrium' between subsidized VC investments and access to GG bank loans is the result of more demand- rather than supply-side forces is hard to say on $a$ priori ground and requires further research endeavours. Second, the covered period of analysis is relatively limited and the results are likely to be more informative about the short-term rather than the long-term effects of the policy intervention. In particular, data over a longer period would permit to assess a more comprehensive evaluation of the policy at the industry level. In relation to the results reported in Section 5.2.1, industry related factors such as capital intensity, technology intensity and failure risks could influence the effect of the policy intervention on the collection of external financial resources by YICs. Third, while it is quite clear that the policy intervention has been effective on the likelihood to obtain external funds and that these funds enhanced YICs' short-term performance, a longer perspective than what was possible to adopt here is needed to gauge the impact of the specific subsidized financing modes on YICs' long-term performance. 


\subsection{Policy implications}

The findings of our study have interesting implications in the realm of the government's role in the entrepreneurial finance market, and on the preferable ways of public activity in the domain of YICs.

First of all, they highlight how a comprehensive policy mechanism, such as the Italian Startup Act, that encompasses different instruments for the subsidization of both debt and equity of the innovative startups does not present serious cannibalization risks and crowdingout effects. Fiscal deductions for equity investments and Government-guaranteed bank loan funds flow towards different types of YICs.

Second, they show that the policy entails a significant reduction for bankers of the negative effects deriving from information asymmetry. As Berger and Udell (1998) pointed out, the main concern for investments in young companies is linked to information asymmetry faced by investors and the risk associated with it (see also Jensen and Meckling, 1976). The Government-guaranteed fund (GG) involves a reduction of the effects of type 1 risk (lending to failure business) for the banks, encouraging them to grant loans also to the younger and smaller YICs. On the opposite side, the fiscal reduction envisaged for equity investments did not seem to have produced shifts on the characteristics of VC targets, but, at the same time, surely contributed to increasing the number of VC investments in the thin Italian VC market (Bertoni et al., 2019). Given the importance that is associated to VC as an external financing resource (Carpenter and Petersen, 2002; Ueda, 2004), and the historical weaknesses experienced in continental Europe to make flourish the VC market (Cosh et al., 2009; Grilli and Murtinu, 2014), this vertical tax-cut type of policy does seem to represent one of the few available policy mechanisms capable to effectively nurture VC in Europe (for similar findings at the European level, while starting from different premises and approaches, see also Henrekson and Sanandaji, 2018 and Grilli et al., 2018b). 
Third, on the other side of the token, our analysis clearly shows how policy complementarities (Rodrik, 1996) in the domain of financial support to innovative entrepreneurship are difficult to achieve. Indeed, this may simply depend on a mere saturation effect on the demand-side, which is not necessarily negative from a social welfare point of view. But it remains that the absence of strong synergies between the two policy mechanisms is also probably revealing the irrelevance of "stamp of approval” phenomena (Lerner, 2002, p. F78) running among the different (subsidized) financial operators.

Acknowledgements. Authors are indebted to the Editor and two anonymous referees for helpful comments and suggestions. We are also thankful to participants to the ENTFIN Conference 2016 held in Lyon, the AiIG Conference 2016 held in Bergamo, the 2018 R\&D Management Conference held in Milan, the Herrenhausen Conference 2019 held in Hanover. We are grateful to Edoardo Girelli, Simone Melchionda, Edoardo Pantanella and Danilo Sesana for valuable research assistance. We also wish to thank Hans Christian Kongsted, Rocco Mosconi and Vera Rocha for their advice in the econometric analysis. Responsibility for any errors lies solely with the authors.

\section{References}

Aerts, K., Matthyssens P., Vandenbempt K., 2007. Critical role and screening practices of European $\quad$ business $\quad$ incubators. Technovation 27, 254-267. http://dx.doi.org/10.1016/j.technovation.2006.12.002

Aghion, P., Howitt, P., 2005. Growth with quality-improving innovations: an integrated framework. Handbook of Economic Growth 1, 67-110. http://dx.doi.org/10.1016/S15740684(05)01002-6

Arrow, K., 1962. Economic welfare and the allocation of resources for invention. In: Nelson, R. (Ed.) 'The rate and direction of inventive activity: economic and social factors'. Princeton University Press, 609-626. 
Barry, C.B., 1994. New directions in research on venture capital finance. Financial Management 23, 3-15.

Baum, J.A., Silverman, B.S., 2004. Picking winners or building them? Alliance, intellectual, and human capital as selection criteria in venture financing and performance of biotechnology startups. Journal of Business Venturing 19 (3), 411-436. http://dx.doi.org/10.1016/S0883-9026(03)00038-7

Beck, T., Demirguc-Kunt, A., 2006. Small and medium-size enterprises: access to finance as a growth constraint. Journal of Banking and Finance 30 (11), 2931-2943. http://dx.doi.org/10.1016/j.jbankfin.2006.05.009

Benfratello, L., Schiantarelli, F., Sembenelli, A., 2008. Banks and innovation: Microeconometric evidence on Italian firms. Journal of Financial Economics 90 (2), 197-217. http://dx.doi.org/ 10.1016/j.jfineco.2008.01.001

Berger, A.N., Udell, G.F., 1998. The economics of small business finance: The roles of private equity and debt markets in the financial growth cycle. Journal of Banking and Finance 22 (6-8), 613-673. http://dx.doi.org/10.1016/S0378-4266(98)00038-7

Bertoni, F., Colombo, M.G., Grilli, L., 2011. Venture capital financing and the growth of hightech start-ups: Disentangling treatment from selection effects. Research Policy 40 (7), 10281043. http://dx.doi.org/10.1016/j.respol.2011.03.008

Bertoni, F., D’Adda, D., Grilli, L., 2019. Self-selection of entrepreneurial firms in thin venture capital markets: Theory and empirical evidence. Strategic Entrepreneurship Journal 13 (1), 47-74. http://dx.doi.org/10.1002/sej.1280

Binks, M.R., Ennew C.T., 1997. The relationship between UK banks and their small business customers. Small Business Economics 9 (2), 167-178. 
Bougheas, S., Mizen P., Yalcin C., 2006. Access to external finance: Theory and evidence on the impact of monetary policy and firm-specific characteristics. Journal of Banking and Finance 30 (1), 199-227. http://dx.doi.org/10.1016/j.jbankfin.2005.01.002

Brame, R., Paternoster, R., Mazerolle, P., Piquero, A., 1998. Testing for the equality of maximum-likelihood regression coefficients between two independent equations. Journal of Quantitative Criminology 14 (3), 245-261. http://dx.doi.org/10.1023/A:1023030312801

Brander, J.A., Du, Q., Hellmann, T.F., 2012. The Effects of Government-Sponsored Venture Capital: International Evidence. Review of Finance 19 (2), 571-618. http://dx.doi.org/10.1093/rof/rfu009

Carpenter, R. E., Petersen, B.C., 2002. Capital Market Imperfections, High-Tech Investment, and New Equity Financing. Economic Journal 112 (477), F54-F72. http://dx.doi.org/10.1111/1468-0297.00683

Chen, H., Miao, J., Wang, N., 2010. Entrepreneurial finance and nondiversifiable risk. The Review of Financial Studies 23(12), 4348-4388. http://dx.doi.org/10.1093/rfs/hhq122

Coad, A., Rao, R., 2008. Innovation and firm growth in high-tech sectors: a quantile regression approach. Research Policy 37 (4), 633-648. http://dx.doi.org/10.1016/j.respol.2008.01.003

Colombo, M.G., Delmastro M., 2002. How effective are technology incubators? Evidence from Italy. Research Policy 31 (7), 1103-1122.

Colombo, M.G., Giannangeli, S., Grilli L., 2012. Public subsidies and the employment growth of high-tech start-ups: assessing the impact of selective and automatic support schemes. Industrial and Corporate Change 22 (5), 1273-1314. http://dx.doi.org/10.1093/icc/dts037

Colombo, M.G., Grilli, L., 2005. Founders’ human capital and the growth of new technologybased firms: A competence-based view. Research Policy 34 (6), 795-816. http://dx.doi.org/10.1016/j.respol.2005.03.010 
Colombo, M.G., Grilli, L., 2007. Funding gaps? Access to bank loans by high-tech start-ups. Small Business Economics 29 (1-2), 25-46. http://dx.doi.org/10.1007/s11187-005-4067-0

Colombo, M.G., Grilli, L. 2010. On growth drivers of high-tech start-ups: Exploring the role of founders' human capital and venture capital. Journal of Business Venturing 25 (6), 610626. http://dx.doi.org/10.1016/j.jbusvent.2009.01.005

Colombo, M.G., Grilli, L, Piscitello, L., Rossi-Lamastra, C., 2011. Science and Innovation Policy for the New Knowledge Economy, Edward Elgar, Cheltenham, UK.

Colombo, M.G., Grilli, L., Verga, C., 2007. High-tech start-up access to public funds and venture capital: Evidence from Italy. International Review of Applied Economics 21 (3), 381-402. http://dx.doi.org/10.1080/02692170701390361

Cooper, R., John, A., 1988. Coordinating coordination failures in Keynesian models. Quarterly Journal of Economics 103 (3), 441-463.

Cosh, A., Cumming, D., Hughes, A., 2009. Outside entrepreneurial capital. The Economic Journal 119 (540), 1494-1533.

Cumming, D., 2007. Government policy towards entrepreneurial finance: innovation investment funds. Journal of Business Venturing 22 (2), 193-235. http://dx.doi.org/10.1016/j.jbusvent.2005.12.002

Cumming, D. J., Grilli, L., Murtinu, S., 2017. Governmental and independent venture capital investments in Europe: A firm-level performance analysis. Journal of Corporate Finance 42, 439-459. http://dx.doi.org/10.1016/j.jcorpfin.2014.10.016

Cumming, D., MacIntosh, J.G., 2006. Crowding out private equity: Canadian evidence. Journal of Business Venturing 21 (5), 569-609. http://dx.doi.org/10.1016/j.jbusvent.2005.06.002

Czarnitzki, D., Delanote, J., 2013. Young innovative companies: the new high-growth firms? Industrial and Corporate Change 22 (5), 1315-1340. http://dx.doi.org/10.1093/icc/dts039 
Czarnitzki, D., Fier A., 2002. Do innovation subsidies crowd out private investment? Evidence from the German service sector. Applied Economics Quarterly 48 (1), 1-25.

Da Rin, M., Nicodano, G., Sembenelli, A., 2006. Public policy and the creation of active venture capital markets. Journal of Public Economics 90 (8-9), 1699-1723. http://dx.doi.org/10.1016/j.jpubeco.2005.09.013

Delmar, F., Davidsson, P., Gartner, W. B., 2003. Arriving at the high-growth firm. Journal of Business Venturing 18(2), 189-216. http://dx.doi.org/10.1016/S0883-9026(02)00080-0

De Cleyn, S.H., Braet J., Klofsten M., 2015. How human capital interacts with the early development of academic spin-offs. International Entrepreneurship and Management Journal 11 (3), 599-621. http://dx.doi.org/10.1007/s11365-013-0294-z

Díaz-Díaz, N.L., Aguiar-Díaz, I., De Saá-Pérez, P., 2008. The effect of technological knowledge assets on performance: The innovative choice in Spanish firms. Research Policy 37 (9), 1515-1529. http://dx.doi.org/10.1016/j.respol.2008.06.002

DiMaggio, P.J., W.W. Powell., 1983. The iron cage revisited: Institutional isomorphism and collective rationality in organizational fields. American Sociological Review 48 (2), 147160.

Dollinger, M.J., Golden P.A., Saxton T., 1997. The effect of reputation on the decision to joint venture. Strategic Management Journal 18 (2), 127-140.

Doornik, J.A., 1999. Object-Oriented Matrix Programming Using Ox, 3rd ed., Timberlake Consultants Press: London.

Durlauf, S.N., 1993. Nonergodic economic growth. The Review of Economic Studies 60 (2), 349-366.

EC-DG ENTR, 2009. European competitiveness report 2008, European Commission, Luxemburg. 
Engel, D., Keilbach, M., 2007. Firm level implications of early stage venture capital investment: An empirical investigation. Journal of Empirical Finance 14 (2), 150-167. http://dx.doi.org/10.1016/j.jempfin.2006.03.004

European Digital Forum, 2016. The 2016 Startup Nation Scoreboard, Policy Briefs, European Commission, Brussels.

Freel, M.S., 2007. Are small innovators credit rationed? Small Business Economics 28 (1), 2335. http://dx.doi.org/10.1007/s11187-005-6058-6

Fritsch, M., Noseleit, F., 2013. Indirect employment effects of new business formation across regions: The role of local market conditions. Papers in Regional Science 92 (2), 361-382. http://dx.doi.org/10.1111/j.1435-5957.2012.00475.x

Ge, C., Huang, K.-W., Png, I.P.L., 2016. Engineer/scientist careers: Patents, online profiles, and misclassification bias. Strategic Management Journal 37 (1), 232-253. http://dx.doi.org/10.1002/smj.2460

Gimmon, E., Levie, J., 2010. Founder's human capital, external investment, and the survival of new high-technology ventures. Research Policy 39 (9), 1214-1226. http://dx.doi.org/10.1016/j.respol.2010.05.017

Giudici, G., Guerini, M., Rossi-Lamastra, C., 2013. Crowdfunding in Italy: State of the Art and Future Prospects. Economia e Politica Industriale - Journal of Industrial and Business Economics 40 (4), 173-188.

Giudici, G., Guerini, M., Rossi-Lamastra, C., 2018. Reward-based crowdfunding of entrepreneurial projects: The effect of local altruism and localized social capital on

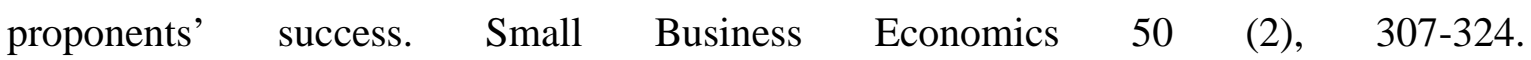
http://dx.doi.org/10.1007/s11187-016-9830-x 
Giudici, G., Paleari, S., 2000. The provision of finance to innovation: A survey conducted among Italian technology-based small firms. Small Business Economics 14 (1), 37-53. http://dx.doi.org/10.1023/A:1008187416389

Giudici, G., Roosenboom P.G.J., 2004. Venture capital and new stock markets in Europe. Advances in Financial Economics, Elsevier. http://dx.doi.org/10.1016/S15693732(04)10001-7

Gloor, P., Dorsaz P., Fuehres H., 2011. Analyzing success of startup entrepreneurs by measuring their social network distance to a business networking hub. Proceedings 3rd international conference on collaborative innovation networks coins, Basel.

Gompers, P., Lerner, J., 2001. The venture capital revolution. Journal of Economic Perspectives 15 (2), 145-168. http://dx.doi.org/10.1257/jep.15.2.145

Gompers, P., Lerner, J., 2004. The Venture Capital Cycle, second edition, MIT Press.

Grilli, L., Mazzucato, M., Meoli, M., Scellato, G., 2018a. Sowing the seeds of the future: Policies for financing tomorrow's innovations. Technological Forecasting and Social Change 127, 1-7. http://dx.doi.org/10.1016/j.techfore.2017.10.021

Grilli, L., Mrkajic, B., Latifi, G., 2018b. Venture capital in Europe: Social capital, formal institutions and mediation effects. Small Business Economics 51 (2), 393-410. http://dx.doi.org/10.1007/s11187-018-0007-7

Grilli, L., Murtinu, S., 2014. Government, venture capital and the growth of European hightech entrepreneurial firms. Research Policy 43 (9), 1523-1543. http://dx.doi.org/10.1016/j.respol.2014.04.002

Hall, B.H., 2002. The financing of research and development. Oxford Review of Economic Policy 18 (1), 35-51.

Hall, B.H., 2005. The financing of innovation. In: Shane, S. (Ed.) The Handbook of Technology and Innovation Management, Wiley, 409-430. 
Hall, B.H., Lerner, J., 2010. The financing of R\&D and innovation. In: Hall B. and N. Rosenberg (Eds.). Handbook of the Economics of Innovation - vol. 1, North Holland, 609639. http://dx.doi.org/10.1016/S0169-7218(10)01014-2

Hall, G., Hutchinson P., Michaelas N., 2000. Industry Effects of the Determinants of unquoted SME’s Capital Structure. International Journal of the Economics of Business 7 (3), 297 312.

Hellmann, T., Puri, M., 2002. Venture capital and the professionalization of start-up firms: Empirical evidence. Journal of Finance 57 (1), 169-197. http://dx.doi.org/10.1111/15406261.00419

Henrekson, M., Sanandaji, T., 2018. Stock option taxation: A missing piece in European innovation policy? Small Business Economics 51 (2), 411-424. http://dx.doi.org/10.1007/s11187-018-0008-6

Hochberg, Y.V., Serrano, C.J., Ziedonis, R.H., 2018. Patent collateral, investor commitment, and the market for venture lending. Journal of Financial Economics 130 (1), 74-94. http://dx.doi.org/10.1016/j.jfineco.2018.06.003

Hsu, D. H., Ziedonis, R. H., 2013. Resources as dual sources of advantage: Implications for valuing entrepreneurial-firm patents. Strategic Management Journal 34 (7), 761-781. http://dx.doi.org/10.1002/smj.2037

Hsu, P.-H., Lee, H.-H., Liu, Z., Zhang, Z., 2015. Corporate Innovation, Default Risk, and Bond Pricing. Journal of Corporate $\quad$ Finance 329-344. http://dx.doi.org/10.1016/j.jcorpfin.2015.09.005

Hsu, P.-H., Tian, X., Xu, Y., 2014. Financial development and innovation: Cross-country evidence. Journal of Financial Economics $112 \quad$ (1), 116-135. http://dx.doi.org/10.1016/j.jfineco.2013.12.002 
Jensen, M.C., Meckling, W.H., 1976. Theory of the firm: Managerial behavior, agency costs and ownership structure. Journal of Financial Economics 3(4), 305-360. http://dx.doi.org/10.1016/0304-405X(76)90026-X

Johnsen, P.C., McMahon R.G.P., 2005. Cross-industry differences in SME financing behaviour: An Australian perspective. Journal of Small Business and Enterprise Development 12 (2), 160-177. http://dx.doi.org/10.1108/14626000510594584

Kortum, S., Lerner, J., 2000. Assessing the contribution of venture capital to innovation. RAND Journal of Economics 31 (4), 674-692. http://dx.doi.org/10.2307/2696354

Kraemer-Eis H., Lang, F., Gvetadze, S., 2014. European small business finance outlook, EIF Research \& Market Analysis, EIF Working papers, 26.

Lee, N., Sameen, H., Cowling, M., 2015. Access to finance for innovative SMEs since the

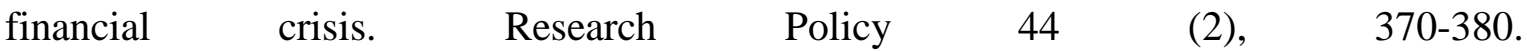
http://dx.doi.org/10.1016/j.respol.2014.09.008

Leland, H.E., Pyle, D.H., 1977. Informational Asymmetries, Financial Structure, and Financial Intermediation. Journal of Finance 32 (2), 371-387.

Leleux, B., Surlemont, B., 2003. Public versus private venture capital: seeding or crowding out? A Pan-European analysis. Journal of Business Venturing 18 (1), 81-104. http://dx.doi.org/10.1016/S0883-9026(01)00078-7

Lerner, J., 2002. When bureaucrats meet entrepreneurs: the design of effective public venture $\begin{array}{llllll}\text { capital programmes. } & \text { Economic Journal } 112 & \text { (477), } & \text { F73-F84. }\end{array}$ http://dx.doi.org/10.1111/1468-0297.00684

Lutz, E., Bender, M., Achleitner, A.K., Kaserer, C., 2013. Importance of spatial proximity between venture capital investors and investees in Germany. Journal of Business Research 66 (11), 2346-2354. http://dx.doi.org/10.1016/j.jbusres.2012.04.016 
Manigart, S., Beuselinck, C., 2001. Supply of venture capital by European governments. Working Paper No. 111, University of Ghent, Belgium.

Manigart, S., Van Hyfte, W., 1999. Post-investment evolution of Belgian venture capital backed companies: an empirical study. Nineteenth Annual Entrepreneurship Research Conference, Babson Center for Entrepreneurial Studies.

Manigart, S., Wright, M., Robbie, K., Desbrieres, P., De Waele, K., 1997. Venture capitalists' appraisal of investment projects: An empirical European study. Entrepreneurship Theory and Practice 21 (4), 29-44.

Mann, W., 2018. Creditor rights and innovation: Evidence from patent collateral. Journal of Financial Economics 130 (1), 25-47. http://dx.doi.org/10.1016/j.jfineco.2018.07.001

Mas-Tur, A., Moya, V.S., 2015. Young innovative companies (YICs) and entrepreneurship $\begin{array}{llllll}\text { policy. Journal of } & \text { Business }\end{array}$ http://dx.doi.org/10.1016/j.jbusres.2015.01.028

Mason, C., Stark M., 2004. What do investors look for in a business plan? A comparison of the investment criteria of bankers, venture capitalists and business angels. International Small Business Journal 22 (3), 227-248. http://dx.doi.org/10.1177/0266242604042377

Mazzucato, M., 2013. Financing innovation: creative destruction vs. destructive creation. Industrial and Corporate Change 22 (4), 851-867. http://dx.doi.org/10.1093/icc/dtt025

Merton, R.K., 1968. The Matthew effect in science: The reward and communication systems of science are considered. Science 159 (3810), 56-63.

Merton, R.K., 1988. The Matthew effect in science, II: Cumulative advantage and the symbolism of intellectual property. Isis 79 (4), 606-623.

Mina, A., Lahr, H., Hughes, A., 2013. The demand and supply of external finance for innovative firms. Industrial and Corporate Change 22 (4), 869-901. http://dx.doi.org/10.1093/icc/dtt020 
Ministry of Economic Development, 2016. Relazione sullo stato di attuazione della normativa a sostegno delle startup e delle PMI innovative - 2016. Relazione annuale al Parlamento, MISE, Rome.

Minniti, M., 2008. The role of government policy on entrepreneurial activity: productive, unproductive, or destructive? Entrepreneurship Theory and Practice 32 (5), 779-790. http://dx.doi.org/10.1111/j.1540-6520.2008.00255.x

Mosconi, R., Seri, R., 2006. Non-causality in bivariate binary time series. Journal of Econometrics 132 (2), 379-407. http://dx.doi.org/10.1016/j.jeconom.2005.02.005

Mulcahy, D., 2013. Six myths about venture capitalists. Harvard Business Review 91 (5), 80-83.

Muzyka, D., Birley, S., Leleux, B., 1996. Trade-offs in the investment decisions of European venture capitalists. Journal of Business Venturing 11 (4), 273-287. http://dx.doi.org/10.1016/0883-9026(95)00126-3

Nelson, R., 1959. The simple economics of basic scientific research. Journal of Political Economy 67 (3), 297-306.

North, D., Baldock, R., Ullah, F., 2013. Funding the growth of UK technology-based small firms since the financial crash: are there breakages in the finance escalator? Venture Capital 15 (3), 237-260. http://dx.doi.org/10.1080/13691066.2013.804755

O’Sullivan, M., 2005. Finance and innovation. In: Fagerberg, J., Mowery, D., Nelson, R. (Eds.) The Oxford Handbook of Innovation, Oxford University Press, 240-265. http://dx.doi.org/10.1093/oxfordhb/9780199286805.003.0009

Packalen, K., 2015. Multiple successful models: how demographic features of founding teams differ between regions and over time. Entrepreneurship \& Regional Development 27 (5-6), 357-385. http://dx.doi.org/10.1080/08985626.2015.1059896 
Parker, S.C., 2002. Do banks ration credit to new enterprises? And should governments intervene? Scottish Journal of Political Economy $49 \quad$ (2), 162-195. http://dx.doi.org/10.1111/1467-9485.00227

Paternoster, R., Brame, R., Mazerolle, P., Piquero, A., 1998. Using the correct statistical test for the equality of regression coefficients. Criminology 36 (4), 859-866. http://dx.doi.org/10.1111/j.1745-9125.1998.tb01268.x

Peneder, M., 2008. The problem of private under-investment in innovation: A policy mind map. Technovation 28 (8), 518-530. http://dx.doi.org/10.1016/j.technovation.2008.02.006

Peters, L., Rice M., Sundararajan M., 2004. The role of incubators in the entrepreneurial process. The Journal of Technology Transfer 29 (1), 83-91.

Plumlee, M., Xie, Y., Yan, M., Yu, J.J., 2015. Bank loan spread and private information: pending approval patents. Review of Accounting Studies 20 (2), 593-638. http://dx.doi.org/10.1007/s11142-014-9304-9

Puri, M., Zarutskie, R., 2012. On the life cycle dynamics of venture capital and non venture capital financed firms. Journal of Finance 67 (6), 2247-2293. http://dx.doi.org/10.1111/j.1540-6261.2012.01786.x

Revest, V., Sapio, A., 2012. Financing technology-based small firms in Europe: What do we know? Small Business Economics 39 (1), 179-205. http://dx.doi.org/10.1007/s11187-0109291-6

Robb, A.M., Watson, J., 2012. Gender differences in firm performance: Evidence from new ventures in the United States. Journal of Business Venturing 27 (5), 544-558. http://dx.doi.org/10.1016/j.jbusvent.2011.10.002

Robinson, K.C., 1999. An examination of the influence of industry structure on eight alternative measures of new venture performance for high potential independent new 
ventures. Journal of Business Venturing 14 (2), 165-187. http://dx.doi.org/10.1016/S08839026(97)00083-9

Rodrik, D., 1996. Coordination failures and government policy: A model with applications to East Asia and Eastern Europe. Journal of International Economics 40 (1-2), 1-22. http://dx.doi.org/10.1016/0022-1996(95)01386-5

Rosenzweig, P., 2014. The Halo Effect:..And The Eight Other Business Delusions that Deceive Managers, Simon and Schuster, New York.

Rothaermel, F.T., 2001. Complementary assets, strategic alliances, and the incumbent's advantage: an empirical study of industry and firm effects in the biopharmaceutical industry. Research Policy 30 (8), 1235-1251. http://dx.doi.org/10.1016/S0048-7333(00)00142-6

Sahlman, W.A., 1990. The structure and governance of venture-capital organizations. Journal of Financial Economics 27 (2), 473-521. http://dx.doi.org/10.1016/0304-405X(90)90065-8

Schäfer, D., Werwatz, A., Zimmermann, V., 2004. The determinants of debt and (private) equity financing: The case of young, innovative SMEs from Germany. Industry and Innovation 11 (3), 225-248. http://dx.doi.org/10.1080/1366271042000265393

Schneider, C., Veugelers, R., 2010. On young highly innovative companies: why they matter and how (not) to policy support them. Industrial and Corporate Change 19 (4), 969-1007. http://dx.doi.org/10.1093/icc/dtp052

Schumpeter, J. A., 1911. The Theory of Economic Development. Cambridge, MA: Harvard University Press.

Storey, D.J., 1994. New firm growth and bank financing. Small Business Economics 6 (2), 139-150. http://dx.doi.org/10.1007/BF01065186

Storey, D.J., 2003. Entrepreneurship, small and medium sized enterprises and public policies. In: Acs, Z.J., Audretsch, D. (Eds.), Handbook of Entrepreneurship Research, Springer, 473511. 
Storey, D.J., Tether, B.S., 1998. Public policy measures to support new technology-based firms in the European Union. Research Policy 26 (9), 1037-1057. http://dx.doi.org/10.1016/S0048-7333(97)00058-9

Teece, D.J., 1986. Profiting from technological innovation: implications for integration, collaboration, licensing, and public policy. Research Policy 15 (6), 285-305. http://dx.doi.org/10.1016/0048-7333(86)90027-2

Timmons, J.A., Spinelli, S., 2003. New Venture Creation: Entrepreneurship for the 21st Century. Boston: McGraw Hill - Irwin.

Ueda, M., 2004. Banks versus venture capital: project evaluation, screening, and expropriation. Journal of Finance 59 (2), 601-621. http://dx.doi.org/10.1111/j.1540-6261.2004.00643.x

VICO, 2011. Policy lessons from the VICO project. Final EU project report (theme SSH-20071.2.3 - Grant Agreement 217485).

Wagner, J., Sternberg R., 2004. Start-up activities, individual characteristics, and the regional milieu: Lessons for entrepreneurship support policies from German micro data. The Annals of Regional Science 38 (2), 219-240. http://dx.doi.org/10.1007/s00168-004-0193-x

Weber, E., Jung S., 2015. The influence of prior experience on innovativeness of startup business ideas. Working paper.

Wynant, L., Hatch, J., Shadbolt, J., Thibeault, A., 1991. Banks and Small Business Borrowers: A 1990 Research Study. University of Western Ontario, Western Business School.

Zacharakis, A.L., Meyer, G.D., 2000. The potential of actuarial decision models: can they improve the venture capital investment decision? Journal of Business Venturing 15 (4), 323346. http://dx.doi.org/10.1016/S0883-9026(98)00016-0

Zúñiga-Vicente, A.J., Alonso-Borrego, C., Forcadell, F.J., Galàn, J.I., 2014. Assessing the effect of public subsidies on firm R\&D investment: a survey. Journal of Economic Surveys 28 (1), 36-67. http://dx.doi.org/10.1111/j.1467-6419.2012.00738.x 


\section{Tables and Figures}

Figure 1 Taxonomy of the different scenarios about the policy effect on YICs of tax benefits on equity investment and government guarantees on bank loans

\begin{tabular}{|l|c|c|}
\hline $\begin{array}{r}\text { Interrelationships between } \\
\text { policy intervention }\end{array}$ & Substitutability & Complementarity \\
Type of YICs & Shadow effect & Matthew effect \\
\hline Same & Task segmentation effect & Halo effect \\
\hline Diverse & & \\
\hline
\end{tabular}

Figure 2 State-transition diagram for the dynamic bivariate survival model

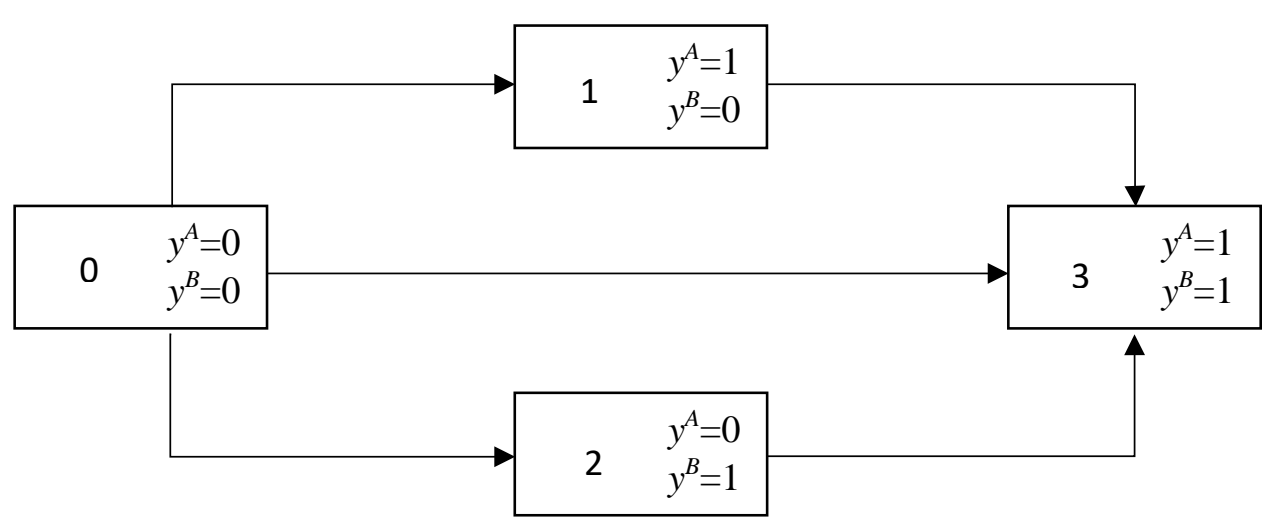


Table 1 VC-backed YICs and YICs accessing the Government-guaranteed (GG) bank loans program

\begin{tabular}{lcc}
\hline & \multicolumn{2}{c}{ Financed YICs } \\
\hline $\begin{array}{l}\text { Financing source (observation period from 2009 } \\
\text { to 2016) }\end{array}$ & $\mathrm{N}^{\circ}$ & $\%$ \\
\hline YICs invested by VC & 276 & 10.9 \\
YICs financed by GG bank loan & 418 & 16.6 \\
YICs financed by VC and GG bank loan & 48 & 1.9 \\
\hline $\begin{array}{l}\text { Second transitions (observation period from 2009 } \\
\text { to 2016) }\end{array}$ & $\mathrm{N}^{\circ}$ & $\%$ \\
\hline $\begin{array}{l}\text { Transition: from VC } \rightarrow \text { VC + GG bank loan } \\
\text { Transition: from GG bank loan } \rightarrow \text { GG bank loan } \\
+ \text { VC }\end{array}$ & 29 & 60.4 \\
$\begin{array}{l}\text { Transition: from nothing } \rightarrow \text { GG bank loan + VC } \\
\text { in the same year }\end{array}$ & 7 & 14.6 \\
\hline
\end{tabular}

Legend: Percentages on the Financing sources (upper part) are computed with reference to the whole sample (2,526 firms). Percentages on second transitions refer to the 48 YICs that received both types of financing. 
Table 2 Definition and source of explanatory variables

\begin{tabular}{|c|c|c|}
\hline Variable & Vector & Description \\
\hline \multicolumn{3}{|l|}{ Firm-specific } \\
\hline Dseed $_{t}$ & & Dummy equal to 1 if $t$ is the firm's foundation year, zero otherwise \\
\hline Age $_{t}$ & $z_{i t}^{j}$ & Age of the firm at $t$ (source: AIDA) \\
\hline$N_{-}$Manager $_{t}$ & $z_{i t}^{j}$ & Number of managers at $t$ (source: AIDA) \\
\hline Employeest $-1_{1}$ & $k_{i t-1}^{j}$ & Number of employees at $t-1$ (source: AIDA) \\
\hline LnTotAsset $t_{t-1}$ & $k_{i t-1}^{j}$ & $\begin{array}{l}\text { Natural logarithm of absolute value of firm total assets at } t-1 \text { (source: } \\
\text { AIDA) }\end{array}$ \\
\hline Leverage $_{t-1}$ & $k_{i t-1}^{j}$ & $\begin{array}{l}\text { Ratio between financial debt at time } t \text { and total assets at } t-1 \text { (source: } \\
\text { AIDA) }\end{array}$ \\
\hline$R O A_{t-1}$ & $k_{i t-1}^{j}$ & $\begin{array}{l}\text { Gross operating margin compared to the total assets at } t-1 \text { (source: } \\
\text { AIDA) }\end{array}$ \\
\hline \multicolumn{3}{|l|}{ Location-specific } \\
\hline DSouth & $z_{i t}^{j}$ & $\begin{array}{l}\text { Dummy for firms located in the South of Italy (1 if they are located } \\
\text { in the South, zero otherwise) }\end{array}$ \\
\hline Industrial Intensity & $z_{i t}^{j}$ & $\begin{array}{l}\text { Regional Industrial intensity where the startup headquarter is located } \\
\text { (Number of firms/100 residents, reference year: 2012, sources: } \\
\text { ISTAT, Istituto G. Tagliacarne, InfoCamere) }\end{array}$ \\
\hline Value Added & $z_{i t}^{j}$ & $\begin{array}{l}\text { Regional incidence on the Italian value added, in percentage terms } \\
\text { (reference year 2011, sources: ISTAT, Istituto G. Tagliacarne, } \\
\text { InfoCamere) }\end{array}$ \\
\hline Infrastructure & $z_{i t}^{j}$ & $\begin{array}{l}\text { Regional infrastructure and economic indicator where the startup } \\
\text { headquarter is located (reference year: 2011, sources: ISTAT, Istituto } \\
\text { G. Tagliacarne, InfoCamere) }\end{array}$ \\
\hline \multicolumn{3}{|l|}{ Macroeconomic-specific } \\
\hline Deficit/GDP ${ }_{t}$ & $z_{i t}^{j}$ & $\begin{array}{l}\text { Italian budget deficit compared to the national GDP at current market } \\
\text { prices at } t \text { (source: EUROSTAT) }\end{array}$ \\
\hline GDPGrowth $t_{t}$ & $z_{i t}^{j}$ & Italian real GDP growth rate at $t$ (source: EUROSTAT) \\
\hline \multicolumn{3}{|l|}{ Sector-specific } \\
\hline Manufacturing sector & $z_{i t}^{j}$ & $\begin{array}{l}\text { Dummy equal to } 1 \text { for companies classified in Manufacturing sector } \\
\text { (source: AIDA) }\end{array}$ \\
\hline$R \& D$ sector & $z_{i t}^{j}$ & $\begin{array}{l}\text { Dummy equal to } 1 \text { for companies classified in R\&D sector (source: } \\
\text { AIDA) }\end{array}$ \\
\hline Software sector & $z_{i t}^{j}$ & $\begin{array}{l}\text { Dummy equal to } 1 \text { for companies classified in Software sector } \\
\text { (source: } A I D A \text { ) }\end{array}$ \\
\hline $\begin{array}{l}\text { General Services } \\
\text { sector }\end{array}$ & & $\begin{array}{l}\text { Dummy equal to } 1 \text { for companies classified in general Services } \\
\text { sector (source: AIDA) }\end{array}$ \\
\hline
\end{tabular}


Table 3 Descriptive statistics for the explanatory variables in the econometric model

\begin{tabular}{|c|c|c|c|c|}
\hline Variable & Mean & Stand. Dev. & Max & Min \\
\hline $\mathrm{Age}_{t}$ & 2.752 & 1.454 & 9.000 & 1.000 \\
\hline$N_{-}$Manager $_{t}$ & 2.538 & 1.854 & 13.000 & 0.000 \\
\hline Employeest $-1_{1}$ & 0.790 & 2.463 & 50.000 & 0.000 \\
\hline LnTotAsset $_{t-1}$ & 7.703 & 5.357 & 16.380 & 0.000 \\
\hline Leverage $_{t-1}$ & 1.043 & 1.021 & 5.889 & 0.000 \\
\hline$R O A_{t-1}$ & -0.094 & 0.465 & 1.799 & -5.500 \\
\hline DSouth & 0.186 & 0.389 & 1.000 & 0.000 \\
\hline Industrial Intensity & 8.950 & 0.718 & 10.200 & 7.570 \\
\hline Value Added & 9.387 & 6.889 & 21.290 & 0.280 \\
\hline Infrastructure & 106.927 & 29.142 & 220.230 & 37.900 \\
\hline Deficit/GDP $P_{t}$ & -2.916 & 0.310 & -2.600 & -4.200 \\
\hline GDPGrowth $_{t}$ & -0.316 & 1.336 & 1.700 & -2.800 \\
\hline Manufacturing sector & 0.207 & 0.405 & 1.000 & 0.000 \\
\hline$R \& D$ sector & 0.175 & 0.380 & 1.000 & 0.000 \\
\hline Software sector & 0.392 & 0.488 & 1.000 & 0.000 \\
\hline General Services sector & 0.223 & 0.416 & 1.000 & 0.000 \\
\hline
\end{tabular}

Legend: Sample: 2,526 firms. Number of observations: 8,093. In particular, 5,493 observations in the Manufacturing sector, 442 in the R\&D sector, 1,035 in the Software sector and 556 in the General Services sector. Statistics on $R O A_{t-1}$ are reported after the winzorisation of the left and right tails at the $0.5 \%$ level. 
Table 4 Determinants of YICs’ access to Venture Capital (VC) and Government-guaranteed (GG) bank loans: dynamic bivariate survival model

\begin{tabular}{|c|c|c|c|}
\hline & First Transitions & Venture Capital $\left(y^{A}\right)$ & GG bank loan $\left(y^{B}\right)$ \\
\hline \multirow[t]{2}{*}{$\alpha_{\text {const }}$} & Constant & $-4.157(0.7253)^{* * *}$ & $-3.210(0.2450)^{* * *}$ \\
\hline & DSeed $_{t}$ & $1.589(0.3901)^{* * *}$ & $3.003(0.3001)^{* * *}$ \\
\hline$\alpha_{1}$ & $\mathrm{Age}_{t}$ & $-0.031(0.0355)$ & $-0.117(0.0254)^{* * *}$ \\
\hline$\beta_{1}$ & Employees $_{t-1}$ & $0.012(0.0123)$ & $-0.031(0.0126)^{* *}$ \\
\hline$\beta_{2}$ & LnTotAsset $_{t-1}$ & $0.123(0.0356)^{* * *}$ & $0.265(0.0267)^{* * *}$ \\
\hline$\alpha_{2}$ & $N_{\_}$Manager $_{t}$ & $0.172(0.0156)^{* * *}$ & $0.017(0.0148)$ \\
\hline$\beta_{3}$ & Leverage $_{t-1}$ & $-0.051(0.0485)$ & $0.009(0.0308)$ \\
\hline$\beta_{4}$ & $R O A_{t-1}$ & $-0.255(0.1034)^{* *}$ & $-0.165(0.0902)^{*}$ \\
\hline$\alpha_{3}$ & DSouth & $0.123(0.1248)$ & $-0.022(0.0898)$ \\
\hline$\alpha_{4}$ & Industrial Intensity & $-0.046(0.0603)$ & $0.063(0.0352)^{*}$ \\
\hline$\alpha_{5}$ & Value Added & $0.010(0.0060)^{*}$ & $0.011(0.0044)^{* *}$ \\
\hline$\alpha_{6}$ & Infrastructure & $0.000(0.0014)$ & $0.000(0.0010)$ \\
\hline$\alpha_{7}$ & Deficit/GDP $t$ & $-0.164(0.1094)$ & $0.690(0.0999)^{* * *}$ \\
\hline$\alpha_{8}$ & GDPGrowth $_{t}$ & $-0.074(0.0256)^{* * *}$ & $0.257(0.0262)^{* * *}$ \\
\hline$\alpha_{9}$ & Manufacturing sector & $0.002(0.106)$ & $\overline{0.424(0.0799) * * *}$ \\
\hline$\alpha_{10}$ & $R \& D$ sector & $-0.180(0.1209)$ & $0.094(0.0894)$ \\
\hline \multirow[t]{2}{*}{$\alpha_{11}$} & Software sector & $0.345(0.0864)^{* * *}$ & $0.102(0.0755)$ \\
\hline & Second Transitions & & \\
\hline$\beta_{B \rightarrow A}$ & $G G \rightarrow V C$ & $0.238(0.2047)$ & - \\
\hline \multirow[t]{2}{*}{$\beta_{A \rightarrow B}$} & $V C \rightarrow G G$ & - & $-0.269(0.1222)^{* *}$ \\
\hline & Simultaneity & & \\
\hline$\gamma_{0}$ & $0 \rightarrow V C+G G$ & & $0.055(0.1484)$ \\
\hline
\end{tabular}

Legend: ${ }^{*} \mathrm{p}<.10 ;{ }^{* *} \mathrm{p}<.05 ;{ }^{* * *} \mathrm{p}<.01$. All two-tailed tests. Robust standard errors in parentheses. Number of firms is 2,526 and number of observations is 8,093 .

Indicates that the coefficients are significantly different at $\mathrm{p}<.05$ (two-tailed $z$-tests). 
Table 5 Determinants of YICs’ access to Venture Capital (VC) and Government-guaranteed (GG) bank loans: dynamic bivariate survival model: Industry sector analysis

\begin{tabular}{|c|c|c|c|c|c|}
\hline & & \multicolumn{2}{|c|}{ Manufacturing-R\&D sector } & \multicolumn{2}{|c|}{ Software-Services sector } \\
\hline & First Transitions & Venture Capital $\left(y^{A}\right)$ & GG bank loan $\left(y^{B}\right)$ & Venture Capital $\left(y^{A}\right)$ & GG bank loan $\left(y^{B}\right)$ \\
\hline \multirow[t]{2}{*}{$\alpha_{\text {const }}$} & Constant & $-7.699(1.6680)^{* * *}$ & $-3.061(0.3301)^{* * *}$ & $-3.500(0.4522)^{* * *}$ & $-3.383(0.3885) * * *$ \\
\hline & DSeed $_{t}$ & $2.750(0.7566)^{* * *}$ & $3.471(0.4400)^{* * *}$ & $1.585(0.4583)^{* * *}$ & $2.928(0.4177)^{* * *}$ \\
\hline$\alpha_{1}$ & $\mathrm{Age}_{t}$ & $-0.047(0.0643)$ & $-0.094(0.0370)^{* *}$ & $-0.029(0.0417)$ & $-0.148(0.0350)^{* * *}$ \\
\hline$\beta_{1}$ & Employeest-1 & $0.005(0.0255)$ & $-0.072(0.0257)^{* * *}$ & $0.012(0.0141)$ & $-0.019(0.0149)$ \\
\hline$\beta_{2}$ & LnTotAssett-1 & $0.230(0.0653)^{* * *}$ & $0.290(0.0386)^{* * *}$ & $0.119(0.0421)^{* * *}$ & $0.275(0.0374)^{* * *}$ \\
\hline$\alpha_{2}$ & $N_{-}$Manager $_{t}$ & $0.159(0.0272)^{* * *}$ & 0.025 (0.0209) & $0.183(0.0189)^{* * *}$ & $0.005(0.0211)$ \\
\hline$\beta_{3}$ & Leverage $_{t-1}$ & $-0.129(0.0854)$ & $0.039(0.0446)$ & $-0.038(0.0576)$ & $0.003(0.0417)$ \\
\hline$\beta_{4}$ & $R O A_{t-1}$ & $-0.663(0.2062)^{* * *}$ & $-0.388(0.1634)^{* *}$ & $-0.233(0.1129)^{* *}$ & $-0.120(0.1081)$ \\
\hline$\alpha_{3}$ & DSouth & $0.204(0.2323)$ & $-0.159(0.1340)$ & $0.173(0.1334)$ & $0.060(0.1250)$ \\
\hline$\alpha_{4}$ & Industrial Intensity & $0.123(0.1164)$ & $0.050(0.0480)$ & $-0.052(0.05801)$ & $0.076(0.0528)$ \\
\hline$\alpha_{5}$ & Value Added & $0.010(0.0117)$ & $0.015(0.0063)^{* *}$ & $0.012(0.0066)^{*}$ & $0.007(0.0063)$ \\
\hline$\alpha_{6}$ & Infrastructure & $0.001(0.0025)$ & $-0.001(0.0015)$ & $0.000(0.00154)$ & $0.001(0.0014)$ \\
\hline$\alpha_{7}$ & Deficit/GDPt & $-0.400(0.1896)^{* *}$ & $0.701(0.1378)^{* * *}$ & $-0.019(0.1326)$ & $0.669(0.1476)^{* * *}$ \\
\hline$\alpha_{8}$ & GDPGrowth $_{t}$ & $-0.075(0.0484)$ & $0.226(0.0365)^{* * *}$ & $-0.063(0.0301)^{* *}$ & $0.281(0.0383)^{* * *}$ \\
\hline \multicolumn{6}{|c|}{ Second Transitions } \\
\hline$\beta_{B \rightarrow A}$ & $G G \rightarrow V C$ & $0.559(0.5905)$ & - & $-0.100(0.3167)$ & - \\
\hline \multirow[t]{2}{*}{$\beta_{A \rightarrow B}$} & $V C \rightarrow G G$ & - & $-0.225(0.2905)$ & - & $-0.284(0.1561)^{* *}$ \\
\hline & Simultaneity & & & & \\
\hline$\gamma_{0}$ & $0 \rightarrow V C+G G$ & \multicolumn{2}{|c|}{$0.299(0.2304)$} & \multicolumn{2}{|c|}{$-0.101(0.1963)$} \\
\hline
\end{tabular}

Legend: * $\mathrm{p}<.10 ; * * \mathrm{p}<.05 ; * * * \mathrm{p}<.01$. All two-tailed tests. Robust standard errors in parentheses. Number of firms is 935 for Manufacturing-R\&D sector and number of observations is 3,095; number of firms is 1,591 for Software-Services and number of observations is 4,998. 
Table 6 Determinants of YICs' access to Venture Capital (VC) and Government-guaranteed (GG) bank loans: augmented dynamic bivariate survival model (with human capital variables)

\begin{tabular}{|c|c|c|c|}
\hline & & \multicolumn{2}{|c|}{ Model } \\
\hline & First Transitions & Venture Capital $\left(y^{A}\right)$ & GG bank loan $\left(y^{B}\right)$ \\
\hline \multirow[t]{2}{*}{$\alpha_{\text {const }}$} & Constant & $-4.100(0.7100)^{* * *}$ & $-2.957(0.2632)^{* * *}$ \\
\hline & DSeed $_{t}$ & $1.588(0.5286)^{* * *}$ & $3.136(0.3763)^{* * *}$ \\
\hline$\alpha_{1}$ & $\mathrm{Age}_{t}$ & $-0.043(0.0486)$ & $-0.076(0.0335)^{* *}$ \\
\hline$\beta_{1}$ & Employeest $-1_{1}$ & $0.007(0.0140)$ & $-0.027(0.0147)^{*}$ \\
\hline$\beta_{2}$ & LnTotAsset $_{t-1}$ & $0.118(0.0465)^{* *}$ & $0.267(0.0321)^{* * *}$ \\
\hline$\alpha_{2}$ & $N \_$Manager $_{t}$ & $0.165(0.0219)^{* * *}$ & $0.038(0.0197)^{*}$ \\
\hline$\beta_{3}$ & Leverage $_{t-1}$ & $-0.054(0.0679)$ & $0.031(0.0428)$ \\
\hline$\beta_{4}$ & $R O A_{t-1}$ & $-0.320(0.1159)^{* * *}$ & $-0.146(0.1093)$ \\
\hline$\alpha_{3}$ & DSouth & $0.189(0.1302)$ & $-0.208(0.1187)^{*}$ \\
\hline$\alpha_{4}$ & Industrial Intensity & $-0.031(0.0385)$ & $0.037(0.0301)$ \\
\hline$\alpha_{5}$ & Value Added & $-0.003(0.0070)$ & $0.008(0.0056)$ \\
\hline$\alpha_{6}$ & Infrastructure & $0.001(0.0015)$ & $0.000(0.0012)$ \\
\hline$\alpha_{7}$ & Deficit/GDP ${ }_{t}$ & $-0.132(0.1477)$ & $0.619(0.1168)^{* * *}$ \\
\hline$\alpha_{8}$ & GDPGrowtht & $-0.110(0.0346)^{* * *}$ & $0.225(0.0328) * * *$ \\
\hline$\alpha_{9}$ & Software sector & $0.630(0.1112)^{* * *}$ & $-0.031(0.1154)$ \\
\hline$\alpha_{10}$ & Technical Education & $0.024(0.0162)$ & $0.023(0.0154)$ \\
\hline$\alpha_{11}$ & Economic Education & $-0.005(0.0039)$ & $-0.006(0.0037)^{*}$ \\
\hline$\alpha_{12}$ & Managerial Experience & $0.013(0.0062)^{* *}$ & $0.008(0.0061)$ \\
\hline$\alpha_{13}$ & Sector Work Experience & $-0.009(0.0116)$ & $-0.021(0.0110)^{*}$ \\
\hline \multirow[t]{2}{*}{$\alpha_{14}$} & Generic Work Experience & $-0.005(0.0145)$ & $-0.030(0.0149) * *$ \\
\hline & Second Transitions & & \\
\hline$\beta_{B \rightarrow A}$ & $G G \rightarrow V C$ & $0.286(0.2582)$ & - \\
\hline \multirow[t]{2}{*}{$\beta_{A \rightarrow B}$} & $V C \rightarrow G G$ & - & $-0.356(0.147)^{* *}$ \\
\hline & Simultaneity & & \\
\hline$\gamma_{0}$ & $0 \rightarrow V C+G G$ & \multicolumn{2}{|c|}{$0.013(0.193)$} \\
\hline
\end{tabular}

Legend: ${ }^{*} \mathrm{p}<.10 ;{ }^{* *} \mathrm{p}<.05 ;{ }^{* * *} \mathrm{p}<.01$. All two-tailed tests. Robust standard errors in parentheses. Number of firms is 1,072 and $n^{\circ}$ of observations is 3,665 . 
Table 7 Determinants of YICs' access to Venture Capital (VC) and Government-guaranteed (GG) bank loans: dynamic bivariate survival model. Estimation with two additional variables: number of incubators and total amount of VC investment per region (NUTS2 level)

\begin{tabular}{|c|c|c|c|}
\hline & & \multicolumn{2}{|c|}{ Model } \\
\hline & First Transitions & Venture Capital $\left(y^{A}\right)$ & GG bank loan $\left(y^{B}\right)$ \\
\hline \multirow[t]{2}{*}{$\alpha_{\text {const }}$} & Constant & $-4.418(0.8708)^{* * *}$ & $-3.226(0.2509)^{* * *}$ \\
\hline & DSeed $_{t}$ & $1.497(0.3985) * * *$ & $2.960(0.3034) * * *$ \\
\hline$\alpha_{1}$ & $\mathrm{Age}_{t}$ & $-0.033(0.0357)$ & $-0.119(0.0254)^{* * *}$ \\
\hline$\beta_{1}$ & Employees $_{t-1}$ & $0.009(0.0126)$ & $-0.031(0.0126)^{* *}$ \\
\hline$\beta_{2}$ & LnTotAsset $_{t-1}$ & $0.128(0.0364)^{* * *}$ & $0.265(0.0267)^{* * *}$ \\
\hline$\alpha_{2}$ & $N_{-}$Manager $_{t}$ & $0.172(0.0156)^{* * *}$ & $0.017(0.0148)$ \\
\hline$\beta_{3}$ & Leverage $_{t-1}$ & $-0.050(0.0486)$ & $0.009(0.0308)$ \\
\hline$\beta_{4}$ & $R O A_{t-1}$ & $-0.272(0.1010)^{* * *}$ & $-0.165(0.0901)^{*}$ \\
\hline$\alpha_{3}$ & DSouth & $0.159(0.1349)$ & $-0.011(0.0907)$ \\
\hline$\alpha_{4}$ & Industrial Intensity & $-0.044(0.0675)$ & $0.061(0.0355)^{*}$ \\
\hline$\alpha_{5}$ & Value Added & $0.019(0.0073)^{* * *}$ & $0.014(0.0062)^{* *}$ \\
\hline$\alpha_{6}$ & Infrastructure & $0.001(0.0015)$ & $0.000(0.0010)$ \\
\hline$\alpha_{7}$ & Deficit/GDP $t$ & $-0.182(0.1123)$ & $0.689(0.1005)^{* * *}$ \\
\hline$\alpha_{8}$ & GDPGrowth $_{t}$ & $-0.072(0.0258)^{* * *}$ & $0.258(0.0264)^{* * *}$ \\
\hline$\alpha_{9}$ & Manufacturing sector & $0.019(0.1068)$ & $0.425(0.0799)^{* * *}$ \\
\hline$\alpha_{10}$ & $R \& D$ sector & $-0.177(0.1215)$ & $0.091(0.0895)$ \\
\hline$\alpha_{11}$ & Software sector & $0.347(0.0871)^{* * *}$ & $0.099(0.0756)$ \\
\hline$\alpha_{12}$ & Incubators & $0.034(0.0130)^{* * *}$ & $0.015(0.0120)$ \\
\hline \multirow[t]{2}{*}{$\beta_{5}$} & VC Investment $t_{-1}$ & $-0.004(0.0017)^{* *}$ & $0.001(0.0013)$ \\
\hline & Second Transitions & & \\
\hline$\beta_{B \rightarrow A}$ & $G G \rightarrow V C$ & $0.261(0.205)$ & - \\
\hline \multirow[t]{2}{*}{$\beta_{A \rightarrow B}$} & $V C \rightarrow G G$ & - & $-0.269(0.1224)^{* *}$ \\
\hline & Simultaneity & & \\
\hline$\gamma_{0}$ & $0 \rightarrow V C+G G$ & \multicolumn{2}{|c|}{$0.060(0.1490)$} \\
\hline
\end{tabular}

Legend: $* \mathrm{p}<.10 ;{ }^{* *} \mathrm{p}<.05 ; * * * \mathrm{p}<.01$. All two-tailed tests. Robust standard errors in parentheses. Number of firms is 2,526 and number of observations is 8,093 . 
Table 8 Determinants of YICs' access to Venture Capital (VC) and Government-guaranteed (GG) bank loans: dynamic bivariate survival model. Estimation with no lagged independent variables in the first transitions

\begin{tabular}{|c|c|c|c|}
\hline & \multirow[b]{2}{*}{ First Transitions } & \multicolumn{2}{|c|}{ Model } \\
\hline & & Venture Capital $\left(y^{A}\right)$ & GG bank loan $\left(y^{B}\right)$ \\
\hline \multirow[t]{2}{*}{$\alpha_{\text {const }}$} & Constant & $-6.927(1.0467)^{* * *}$ & $-3.333(0.2909)^{* * *}$ \\
\hline & Dseed $_{t}$ & $0.480(0.1084)^{* * *}$ & $0.257(0.0914) * * *$ \\
\hline$\alpha_{1}$ & $\mathrm{Age}_{t}$ & $-0.061(0.0375)$ & $-0.117(0.0266)^{* * *}$ \\
\hline$\alpha_{2}$ & Employees $_{t}$ & $-0.011(0.0097)$ & $-0.008(0.0079)$ \\
\hline$\alpha_{3}$ & LnTotAsset $_{t}$ & $0.401(0.0321)^{* * *}$ & $0.294(0.0255)^{* * *}$ \\
\hline$\alpha_{4}$ & $N_{-}$Manager $_{t}$ & $0.106(0.0180)^{* * *}$ & $0.003(0.0164)$ \\
\hline$\alpha_{5}$ & Leverage $_{t}$ & $-0.370(0.0476)^{* * *}$ & $0.169(0.0244) * * *$ \\
\hline$\alpha_{6}$ & $R O A_{t}$ & $-0.565(0.0646)^{* * *}$ & $-0.262(0.0735)^{* * *}$ \\
\hline$\alpha_{7}$ & DSouth & $0.201(0.1513)$ & $-0.143(0.1026)$ \\
\hline$\alpha_{8}$ & Industrial Intensity & $-0.038(0.0793)$ & $0.031(0.0381)$ \\
\hline$\alpha_{9}$ & Value Added & $0.004(0.0073)$ & $0.005(0.0047)$ \\
\hline$\alpha_{10}$ & Infrastructure & $0.001(0.0016)$ & $-0.000(0.0011)$ \\
\hline$\alpha_{11}$ & Deficit/GDP ${ }_{t}$ & $-0.097(0.1293)$ & $0.740(0.1095)^{* * *}$ \\
\hline$\alpha_{12}$ & GDPGrowth $_{t}$ & $-0.067(0.0291)^{* *}$ & $0.256(0.0279) * * *$ \\
\hline$\alpha_{13}$ & Manufacturing sector & $-0.069(0.1214)$ & $0.303(0.0887)^{* * *}$ \\
\hline$\alpha_{14}$ & $R \& D$ sector & $-0.214(0.1380)$ & $0.161(0.0968)$ \\
\hline \multirow[t]{2}{*}{$\alpha_{15}$} & Software sector & $0.368(0.1004)^{* * *}$ & $0.101(0.0832)$ \\
\hline & Second Transitions & & \\
\hline$\beta_{B \rightarrow A}$ & $G G \rightarrow V C$ & $0.360(0.2264)$ & - \\
\hline \multirow[t]{2}{*}{$\beta_{A \rightarrow B}$} & $V C \rightarrow G G$ & - & $-0.289(0.1274)^{* *}$ \\
\hline & Simultaneity & & \\
\hline$\gamma_{0}$ & $0 \rightarrow V C+G G$ & \multicolumn{2}{|c|}{0.095 (0.1618) } \\
\hline
\end{tabular}

Legend: $* \mathrm{p}<.10 ; * * \mathrm{p}<.05 ; * * * \mathrm{p}<.01$. All two-tailed tests. Robust standard errors in parentheses. Number of firms is 2,526 and number of observations is 8,093 . 
Table 9 Determinants of YICs’ access to Venture Capital (VC) and Government-guaranteed (GG) bank loans: seemingly unrelated bivariate probit model

\begin{tabular}{|c|c|c|c|}
\hline \multicolumn{4}{|c|}{ Model } \\
\hline & First Transitions & Venture Capital $\left(y^{A}\right)$ & GG bank loan $\left(y^{B}\right)$ \\
\hline \multirow[t]{2}{*}{$\alpha_{\text {const }}$} & Constant & $-4.870(0.7433)^{* * *}$ & $0.286(0.6961)$ \\
\hline & Dseed $_{t}$ & $3.785(0.2880)^{* * *}$ & $3.115(0.2880)^{* * *}$ \\
\hline$\alpha_{1}$ & $\mathrm{Age}_{t}$ & $-0.026(0.0241)$ & $-0.156(0.0228)^{* * *}$ \\
\hline$\beta_{1}$ & Employeest $-1_{1}$ & $-0.003(0.0086)$ & $-0.020(0.0102)^{* *}$ \\
\hline$\beta_{2}$ & LnTotasset $_{t-1}$ & $0.370(0.0253)^{* * *}$ & $0.273(0.0259)^{* * *}$ \\
\hline$\alpha_{2}$ & $N_{-}$Manager $_{t}$ & $0.181(0.0123)^{* * *}$ & $0.035(0.0140)^{* *}$ \\
\hline$\beta_{3}$ & Leverage $_{t-1}$ & $-0.263(0.0348)^{* * *}$ & $0.073(0.0265)^{* * *}$ \\
\hline$\beta_{4}$ & $R O A_{t-1}$ & $-0.697(0.0614)^{* * *}$ & $-0.251(0.0818)^{* * *}$ \\
\hline$\alpha_{3}$ & DSouth & $0.117(0.1060)$ & $-0.375(0.1031)^{* * *}$ \\
\hline$\alpha_{4}$ & Industrial Intensity & $-0.139(0.0553)^{* *}$ & $-0.125(0.0508)^{* *}$ \\
\hline$\alpha_{5}$ & Value Added & $0.003(0.0049)$ & $-0.002(0.0046)$ \\
\hline$\alpha_{6}$ & Infrastructure & $0.000(0.0012)$ & $-0.003(0.0011)^{* *}$ \\
\hline$\alpha_{7}$ & Deficit/GDP $t$ & $0.043(0.0957)$ & $1.136(0.1167)^{* * *}$ \\
\hline$\alpha_{8}$ & GDPGrowth $_{t}$ & $-0.014(0.0200)$ & $0.329(0.0272)^{* * *}$ \\
\hline$\alpha_{9}$ & Manufacturing sector & $0.037(0.0831)$ & $0.456(0.0735)^{* * *}$ \\
\hline$\alpha_{10}$ & $R \& D$ sector & $-0.184(0.0940)^{*}$ & $0.151(0.0808)^{*}$ \\
\hline \multirow[t]{2}{*}{$\alpha_{11}$} & Software sector & $0.452(0.0691)^{* * *}$ & $0.084(0.0700)$ \\
\hline & Second Transitions & & \\
\hline$\beta_{B \rightarrow A}$ & $G G \rightarrow V C$ & $-0.110(0.1828)$ & - \\
\hline$\beta_{A \rightarrow B}$ & $V C \rightarrow G G$ & - & $-0.387(0.1694)^{* *}$ \\
\hline
\end{tabular}

Legend: $* \mathrm{p}<.10 ;{ }^{* *} \mathrm{p}<.05 ; * * * \mathrm{p}<.01$. All two-tailed tests. Robust standard errors in parentheses. Number of firms is 2,526 and number of observations is 8,093 . 
Table 10 Number of investors, number of deals, average and maximum number of deals implemented with equity issuance and GG lending in the sample YICs from 2009 to 2016

\begin{tabular}{ccccc}
\hline Type of investor & $\begin{array}{c}\text { Number of } \\
\text { investors }\end{array}$ & $\begin{array}{c}\text { Total number } \\
\text { of deals }\end{array}$ & Mean & Max \\
\hline Venture Capital & 116 & 276 & 1.57 & 18 \\
Bank & 101 & 418 & 2.58 & 44 \\
\hline
\end{tabular}

Table 11 Characteristics of investors and number of deals: random effects panel data estimates. The dependent variables are (i) Loanst (the number of GG loans granted by each bank in the sample YICs during year $t$ ), (ii) VC Investments (the number of equity investments made by professional VCs in the sample YICs during year $t$ )

\begin{tabular}{cccc}
\hline & Analysis type & Random effects & Random effects \\
\hline$\alpha_{\text {const }}$ & Dependent Variable & Loans $_{t}$ & VC Investments $_{t}$ \\
$\beta_{1}$ & Constant & $-2.215(1.4387)$ & $1.808(0.2341)^{* * *}$ \\
$\beta_{2}$ & LnConsAsset $_{t}$ & $0.520(0.1415)^{* * *}$ & - \\
$\beta_{3}$ & Foreign Headquarter & - & $0.049(0.0878)$ \\
$\beta_{4}$ & International Branch & $-1.149(1.0490)$ & $-0.814(0.5051)$ \\
$\beta_{5}$ & Local Bank & $-0.280(0.5287)$ & - \\
$\beta_{6}$ & Startup Program & $4.909(1.0886)^{* * *}$ & - \\
\hline
\end{tabular}

Legend: $* \mathrm{p}<.10 ; * * \mathrm{p}<.05 ; *^{* *} \mathrm{p}<.01$. All two-tailed tests. Robust standard errors in parentheses. Number of observations is 164 for Loans and 148 for VC Investments. 
Table 12 Determinants of YICs' performance: panel data random effects model. The dependent variables are: (i) LnSales $t$ which is the logarithm of the total annual sales of firm $i$ during year $t$, (ii) TotEmployees, the number of employees reported by firm $i$ at the end of year $t$

\begin{tabular}{lcc}
\hline Analysis type & \multicolumn{2}{c}{ Random effects } \\
\hline Dependent Variable & \multicolumn{1}{c}{ LnSales $_{t}$} & TotEmployees $_{t}$ \\
\hline Constant & $6.737(2.2458)^{* * *}$ & $-0.498(1.669)$ \\
$V C_{t-1}$ & $1.302(0.2455)^{* * *}$ & $2.736(0.218)^{* * *}$ \\
$G G_{t-1}$ & $0.184(0.2683)$ & $0.932(0.250)^{* * *}$ \\
Age $_{t}$ & $0.470(0.0519)^{* * *}$ & $0.515(0.043)^{* * *}$ \\
Leverage $_{t-1}$ & $0.490(0.0585)^{* * *}$ & $0.215(0.052)^{* * *}$ \\
ROA $_{t-1}$ & $0.971(0.1512)^{* * *}$ & $0.430(0.131)^{* * *}$ \\
DSouth & $-0.703(0.3682)^{*}$ & $0.794(0.259)^{* * *}$ \\
Industrial Intensity $^{* *}$ & $0.102(0.1874)$ & $0.123(0.133)$ \\
Value Added & $-0.023(0.0177)$ & $0.023(0.013)^{*}$ \\
Infrastructure $_{\text {Deficit/GDP }} t$ & $0.003(0.0039)$ & $-0.002(0.003)$ \\
GDPGrowth & $0.140(0.2347)$ & $0.440(0.239)^{*}$ \\
Manufacturing sector & $-0.734(0.2648)^{* * *}$ & $0.243(0.192)$ \\
R\&D sector & $-1.567(0.2722)^{* * *}$ & $-0.442(0.198)^{* *}$ \\
Software sector & $-0.189(0.2280)$ & $0.579(0.165)^{* * *}$ \\
\hline
\end{tabular}

Legend: $* \mathrm{p}<.10 ; * * \mathrm{p}<.05 ; * * * \mathrm{p}<.01$. All two-tailed tests. Robust standard errors in parentheses. Number of firms is 2,195, with 4,748 observations for LnSales $t_{t}$ equation and 2,402 (4,984 observations) for TotEmployees ${ }_{t}$ equation. 


\section{Appendix}

Table A1 Correlation matrix of the explanatory variables. * $\mathrm{p}<.10$; ** $\mathrm{p}<.05$; *** $\mathrm{p}<.01$. All two-tailed tests

\begin{tabular}{|c|c|c|c|c|c|c|c|c|c|c|c|c|c|c|c|c|}
\hline & (1) & (2) & (3) & (4) & (5) & (6) & (7) & (8) & (9) & (10) & (11) & (12) & (13) & (14) & (15) & (16) \\
\hline (1) DSeed $_{t}$ & 1 & & & & & & & & & & & & & & & \\
\hline (2) $A g e_{t}$ & $-0.635^{* * *}$ & 1 & & & & & & & & & & & & & & \\
\hline (3) Employees & $-0.223^{* * *}$ & $0.317^{* * *}$ & 1 & & & & & & & & & & & & & \\
\hline (4) LnTotAsset $t_{t-1}$ & $-0.969 * * *$ & $0.688^{* * *}$ & $0.325^{* * *}$ & 1 & & & & & & & & & & & & \\
\hline (5) $N \_$Manager $_{t}$ & $-0.099 * * *$ & $0.139 * * *$ & $0.185^{* * *}$ & $0.156^{* * *}$ & 1 & & & & & & & & & & & \\
\hline (6) Leverage & $-0.505^{* * *}$ & $0.376^{* * *}$ & $0.200^{* * *}$ & $0.546^{* * *}$ & -0.014 & 1 & & & & & & & & & & \\
\hline (7) $R O A_{t-1}$ & $0.136 * * *$ & $-0.066 * * *$ & $-0.031 * * *$ & $-0.076^{* * *}$ & $-0.027 * *$ & 0.020 & 1 & & & & & & & & & \\
\hline (8) Dsouth & $0.019 *$ & -0.001 & $0.036^{* * *}$ & $-0.041^{* * *}$ & $-0.077 * * *$ & $-0.074 * * *$ & 0.009 & 1 & & & & & & & & \\
\hline $\begin{array}{l}\text { (9) Industrial } \\
\text { Intensity }\end{array}$ & -0.013 & 0.010 & $-0.022^{*}$ & 0.013 & 0.002 & $0.026 * *$ & $0.030^{* * *}$ & $-0.350^{* * *}$ & 1 & & & & & & & \\
\hline (10) Value Added & 0.010 & $-0.048 * * *$ & 0.001 & 0.008 & $0.059 * * *$ & $0.031^{* * *}$ & $-0.052 * * *$ & $-0.369 * * *$ & $-0.359 * * *$ & 1 & & & & & & \\
\hline (11) Infrastructure & -0.015 & 0.014 & $-0.027^{* *}$ & $0.021^{*}$ & $0.052^{* * *}$ & 0.010 & 0.002 & $-0.392 * * *$ & $-0.235 * * *$ & $0.141^{* * *}$ & 1 & & & & & \\
\hline (12) Deficit/GDP $P_{t}$ & $-0.449 * * *$ & $0.350^{* * *}$ & $0.138^{* * *}$ & $0.432 * * *$ & $-0.048^{* * *}$ & $0.252 * * *$ & $-0.095 * * *$ & $0.021 *$ & -0.011 & $0.019 *$ & -0.014 & 1 & & & & \\
\hline (13) GDPGrowth & $-0.264^{* * *}$ & $0.262^{* * *}$ & $0.086^{* * *}$ & $0.248^{* * *}$ & -0.018 & $0.150^{* * *}$ & $-0.085 * * *$ & $0.019 *$ & $-0.019 *$ & 0.008 & -0.017 & $0.151^{* * *}$ & 1 & & & \\
\hline $\begin{array}{l}\text { (14) Manufacturing } \\
\text { sector }\end{array}$ & -0.017 & $0.031^{* * *}$ & $0.022^{*}$ & 0.047 & $0.044^{* * *}$ & $0.074^{* * *}$ & $0.025 * *$ & $-0.019 *$ & $0.085 * * *$ & $-0.080^{* * *}$ & $-0.035^{* * *}$ & $-0.035 * * *$ & -0.004 & 1 & & \\
\hline (15) $R \& D$ sector & -0.006 & $0.023^{* *}$ & $-0.063 * * *$ & $0.004 * * *$ & $0.040^{* * *}$ & $-0.039 * * *$ & $0.056^{* * *}$ & 0.008 & 0.002 & $-0.049 * * *$ & $0.033^{* * *}$ & $-0.021^{*}$ & 0.013 & $-0.236 * * *$ & 1 & \\
\hline (16) Software sector & $0.021^{*}$ & $-0.061 * * *$ & $0.039^{* * *}$ & -0.039 & $-0.046 * * *$ & -0.040 & $-0.076 * * *$ & $0.020^{*}$ & $-0.059 * * *$ & $0.056^{* * *}$ & -0.005 & $0.046^{* * *}$ & 0.010 & $-0.410^{* * *}$ & $-0.370^{* * *}$ & 1 \\
\hline
\end{tabular}


Table A2 Definition of entrepreneurs' human capital variables

\begin{tabular}{ll}
\hline Variable & Description and source \\
\hline Human Capital-specific & \\
\hline Technical Education & $\begin{array}{l}\text { Average years of founders' scientific and/or technical education at } \\
\text { graduate and post-graduate level (source: Telemaco and LinkedIn) } \\
\text { Average years of founders' economic and/or managerial education at } \\
\text { graduate and post-graduate level (source: Telemaco and LinkedIn) } \\
\text { Average years of founders' managerial experience (source: } \\
\text { Telemaco and LinkedIn) }\end{array}$ \\
Sector Work Experience & $\begin{array}{l}\text { Average years of founders' work experience in the same sector of } \\
\text { the firm before foundation (source: Telemaco and LinkedIn) } \\
\text { Average years of founders'work experience in other sectors before } \\
\text { firm's foundation (source: Telemaco and LinkedIn) }\end{array}$ \\
\hline
\end{tabular}

Table A3 Descriptive statistics for entrepreneurs' human capital variables

\begin{tabular}{lcccc}
\hline Variable & Mean & Stand. Dev. & Max & Min \\
\hline Technical Education & 6.142 & 10.952 & 74.000 & 0.000 \\
Economic Education & 1.712 & 5.060 & 75.000 & 0.000 \\
Managerial Experience & 1.688 & 3.476 & 28.000 & 0.000 \\
Sector Work Experience & 3.102 & 5.037 & 38.000 & 0.000 \\
Generic Work Experience & 1.236 & 3.237 & 40.000 & 0.000 \\
\hline
\end{tabular}

